\title{
Effectiveness of Gum Arabic, Potassium Salts and Their Incorporation in The Control of Postharvest Diseases and Maintaining Quality of 'Washington' Navel Oranges during Long Term Cold Storage
}

\author{
A. F. Abd El-Khalek \\ Horticulture Department, Faculty of Agriculture, Tanta University, 31527, Egypt.
}

$\mathbf{E}$ DIBLE coating of gum arabic (GA) and food preservatives with antifungal properties included potassium sorbate (PS) and potassium bicarbonate (PB) were evaluated on 'Washington' navel oranges during long term cold storage in 2016 and 2017 seasons. Orange fruits were dipped for three minutes into the following treatments: distilled water and used for untreated fruits (control), 0.2\% imazalil (IMZ) and used as a commercial fungicide, 10\% GA, 2\% PS, 2\% $\mathrm{PB}, 0.2 \% \mathrm{IMZ}$ incorporated with 10\% GA, 2\% PS incorporated with 10\% GA and 2\% PB incorporated with $10 \%$ GA. After that, all treatments stored at $5 \pm 1^{\circ} \mathrm{C}$ and $90 \pm 5 \%$ relative humidity (RH) for ten weeks followed by one week as a shelf life period at $18-23^{\circ} \mathrm{C}$ and $55 \pm 5 \% \mathrm{RH}$. The changes in physical and chemical characteristics of orange fruits were determined every two weeks intervals of cold storage periods followed by one week shelf life. In general, all postharvest treatments effectively reduced fruit weight loss, controlled decay incidence, decreased size of lesion surface diameter, increased marketable fruit percentage, maintained rind firmness and retained fruit visual appearance as compared to untreated oranges and treated with IMZ during storage period. Moreover, these applications significantly decreased loss of fruit juice, ascorbic acid, titratable acidity (TA) as well as significantly slowed the accumulation of total soluble solids (TSS) and TSS/TA ratio. In addition, these applications increased total phenolic content and enhanced total antioxidant capacity of oranges as compared to untreated fruits. In particular, $2 \%$ PS or $2 \%$ PB incorporated with $10 \%$ GA coating applications were the most effective in this aspect in comparison to the other treated and untreated fruits. Thus, these applications showed an easy and inexpensive approach as a suitable alternative to the currently adopted IMZ application for controlling postharvest decay and suppressing the deterioration of physical and chemical characteristics of 'Washington' navel oranges during long term storage at low temperature.

Keywords: Navel oranges, Edible coating, Gum arabic, Potassium sorbate, Potassium bicarbonate, Decay, Antioxidant capacity, Total phenolic, Postharvest quality.

\section{Introduction}

Citrus is a very economically important crop in many tropical and sub-tropical countries throughout the world (Murata, 1997). Navel orange is one of the commercially important cultivar in this group. Recently, citrus has become an important fruit crop in the world trade for fresh fruits and its processed products because are consumed fresh and/or juiced. In addition to its economic rewards the fruits are a source of valuable nutrients and bioactive components such as ascorbic acid, folic acid, dietetic fiber, carotenoids, essential oils, pectin and phenolic compounds (Balasundram et al., 2006). In Egypt, citrus is one of the most popular fruits and navel oranges enjoy the most significant importance for local market and export markets (Omran et al., 2002). The total area of citrus in Egypt occupy about 485940 feddans, out of which 418415 feddans are fruiting, yielded about 4272886 tons as annual fruit production, whereas the total area of orange occupy about 329496 feddans, out of which 288724 feddans are fruiting, yielded about 3297593 tons as annual fruit production

Corresponding author: e-mail: ahmed5474946@yahoo.com

DOI: $10.21608 /$ ejoh.2018.3561.1062

C2017 National Information and Documentation Centre (NIDOC) 
(Anonymous, 2017). However, citrus fruit is susceptible to a number of pathogens such as green mould (Penicillium digitatum), blue mould (Penicillium italicum), sour rot (Geotrichum candidum) and black mould (Aspergillus niger) through wound and/or injuries inflicted during harvesting and handling of fruit that affect the considerably deteriorate the fruit quality (Eckert and Eaks, 1989). In addition, citrus fruits that are in contact with waste materials, disease pathogen, fungi, bacteria are not suitable for export (Prusky, 2011). The success of fresh citrus fruit export is mainly dependant on the quality of produce, phytosanitary conditions set by the importing country, world trade organization and the postharvest management to minimize the decay till the consignment reaches to its destination. Synthetic fungicide such as imazalil, thiabendazole and sodium orthophenylphenate incorporated into waxes in the citrus packinghouses is one of the most important steps for controlling postharvest decay in citrus packinghouses. However, the widespread use of these fungicides in commercial packinghouses has led to the proliferation of resistant isolates of fungal pathogens, thus their effectiveness have considerably reduced (Palou et al., 2008). Furthermore, prolonged and extensive use of synthetic chemical fungicides either alone or into conventional waxes may deposit harmful residues on fruit surface with increasing concerns of human health hazards and environmental contamination due to the use of large quantities of chemicals (Palou et al., 2008 and Youssef et al., 2014).

Nowadays, all imported countries have enforced strict import regulations regarding the maximum residue for such chemical treatments of citrus fruits and consumers prefer purchasing the fruits that are not treated with fungicides, free from defects and disease because it is safer for consumption. Therefore, new non-toxic methods for controlling postharvest diseases have shifted towards prioritizing alternatives to synthetic fungicides (Palou et al., 2008). Among the alternative curative methods against citrus postharvest decay with maintain the fruit quality are common antimicrobial food preservatives such as potassium sorbate (Palou et al., 2002, Smilanick et al., 2008, MontesinosHerrero et al., 2009 and Parra et al., 2014) and potassium bicarbonate (Youssef et al., 2014). These salts are a safer to consumers, workers and environment thus approved as generally regarded as safe (GRAS) compounds and classified as a minimal risk active ingredient and exempt from residue tolerances by the European Food Safety Authority and the United States Food and Drug Administration (Lindsay, 1996). In this context, control of postharvest decay of green and blue mold was achieved by potassium sorbate alone (Palou et al., 2002, Smilanick et al., 2008 and Parra et al., 2014) or in combination with imazalil and thiabendazole even when tested against a resistant isolate of Penicillium digitatum and Penicillium italicum (Montesinos-Herrero et al., 2009). Moreover, low toxicity salts of potassium sorbate, sodium bicarbonate and potassium phosphite were controlled postharvest diplodia and phomopsis stem end rot of 'Eureka' lemons (Cerioni et al., 2013 and Cerioni et al., 2017). Incorporated potassium sorbate, carbonate and bicarbonate at $6 \%$ concentration in wax significantly reduced the postharvest decay incidence and decrease the weight loss reduction of citrus fruits (Youssef et al., 2012a). Also, pre or post harvest application of potassium sorbate, potassium carbonate or potassium bicarbonate at $2 \%$ reduced postharvest decay of clementines cv. 'Comune' and oranges cv. 'Valencia' during cold storage at $6^{\circ} \mathrm{C}$ and $4^{\circ} \mathrm{C}$, respectively for two months followed by seven days shelf life at $20 \pm 2{ }^{\circ} \mathrm{C}$ (Youssef et al., 2012b). Moreover, dipping 'Tarocco' and 'Valencia late' oranges in $3 \%$ potassium bicarbonate reduced the percentage of postharvest decay during cold storage and shelf life and could be efficiently using as alternative treatment for conventional synthetic fungicides (Youssef et al., 2014). In addition, applications of potassium sorbate at $2 \%$ individually or plus hydrogen peroxide at $2 \%$ controlled postharvest diseases of 'Eureka' lemons for two weeks at $20^{\circ} \mathrm{C}$ (Cerioni et al., 2013).

The application of wax coatings is a critical operation in citrus fruit packinghouses, which create a protective barrier that is providing the required shine and gloss on which aesthetic value, protecting weight loss reduction (Wild, 1981). Nevertheless, an increase of stem-end rot and internal core rot caused by Alternaria citri, Diplodia natalensis and Fusarium spp. were observed on citrus fruit treated with different commercial waxes (Wild, 1981 and Waks et al., 1985). Thus, natural products are taking a place as an alternative approach for reducing postharvest deterioration of fruit (Tripathi and Dubey, 2004). Edible coatings are considered an environmentally friendly alternative method able to extend the postharvest life of fresh

Egypt. J. Hort. Vol. 45, No.2 (2018) 
fruits and vegetables (Dhall, 2013). They form a semi-permeable barrier to gas exchange and water vapor that reduce weight loss because of preventing dehydration of the coated product and decrease metabolic processes such as respiration and ethylene production rates, hence delay fruits senescence. Various compounds have been used as edible coatings and are commonly based on proteins, lipids and polysaccharides. Gum arabic (GA) is a polysaccharide natural secretion from stems and branches of Acacia species and is composed of galactose, rhamnose, arabinose and glucoronic acid (Idris et al., 1998). Gum arabic is considered as GRAS compounds. It is widely used extensively in the industrial sector because of its emulsification, film forming and encapsulation properties (Nisperos-Carriedo, 1994). Postharvest coated apples with gum arabic significantly reduced decay incidence, weight loss percentage, softness and colour development as well as maintained internal quality during cold storage as compared to uncoated fruits (El-Anany et al., 2009). Moreover, $10 \%$ gum arabic coating alone or combined with lemongrass oil or cinnamon oil controlled anthracnose and maintained quality of banana and papaya fruits (Maqbool et al., 2011). Pre-storage treatment of mangoes with gum arabic at $10 \%$ alone or incorporated with calcium chloride at $3 \%$ effectively reduced decay incidence, weight loss, colour changes and soluble solid content as well as efficiently maintained high firmness, ascorbic acid, titratable acidity (Khaliq et al., 2015). Additionally, gum arabic coating effectively maintained total antioxidant and total phenolic content in papaya fruits (Addai et al., 2013) and mangoes (Khaliq et al., 2016).

Therefore, the objective of this work was to study the effect of utilization of new edible coating with gum arabic and food additives of potassium sorbate and bicarbonate as a low-toxicity or noncontaminant antifungal methods on postharvest decay and maintaining quality of 'Washington' navel oranges during long term storage at $5 \pm 1^{\circ} \mathrm{C}$ and $90 \pm 5 \%$ relative humidity (RH).

\section{Materials and Methods}

Fruit material, preparation of soaking solutions and treatments

During 2016 and 2017 seasons commercially mature of 'Washington' navel oranges (Citrus sinensis (L.) Osbeck) were harvested randomly from a private orchard at El-Asher min Ramadan city, El-Sharqia Governorate, Egypt (latitude, $31^{\circ} 74^{\prime} \mathrm{N}$, longitude, $30^{\circ} 29^{\prime} \mathrm{E}$ ). The trees grafted on 'Sour Orange' rootstock, were about 15 years of age, planted at a spacing of $6 \times 5$ meters apart in sandy soil under drip irrigation system and subjected to standard agriculture practices recommended by ministry of agriculture and land reclamation. Fruit were directly transported in plastic boxes (15 kg capacity) to Department of Horticulture, Faculty of Agriculture, Tanta University, Egypt. At the laboratory, orange fruits sorted to eliminate defects. Samples of fruit of uniform size and appearance were washed by $2 \%$ sodium hypochlorite water solution for $2 \mathrm{~min}$ to clean the surface of fruits and completely air dried at room temperature. A total of 1008 clean sound oranges were selected and randomly divided into eight treatment with three replicates and each replicate contained seven individual fruit $(8$ treatments $\mathrm{x} 6$ periods of storage $\times 3$ replicates $\times$ 7 fruits).

Gum arabic (GA) powder of food grade was purchased from Sigma Chemical Company, Egypt. GA solution at $10 \%(\mathrm{w} / \mathrm{v})$ was prepared by dissolving $500 \mathrm{~g}$ of gum arabic powder in 5 liter of distilled water. The solution of GA was stirred with low heat at $40^{\circ} \mathrm{C}$ for $60 \mathrm{~min}$ by using a hot plate with magnetic stirrer (Model: 502P-2 USA), then filtered using muslin cloth to remove impurities and any undissolved materials. After cooling the solution to $20^{\circ} \mathrm{C}$, glycerol monostearate at $1 \%$ was added as a plasticizer to improve the strength and flexibility of the coating solution. The $\mathrm{pH}$ of the solution was adjusted to 5.6 with $1 \mathrm{~N} \mathrm{NaOH}$ using a digital pH meter (Model: AD1000, Romania). Potassium sorbate (PS) or potassium bicarbonate (PB) solution at $2 \%(\mathrm{w} / \mathrm{v})$ was prepared by dissolving 100 grams of PS or PB in 5 liter of distilled water. Imazalil (IMZ) solution at $0.2 \%(\mathrm{v} / \mathrm{v})$ was prepared by adding $10 \mathrm{ml}$ of IMZ in 5 liter of distilled water. For the incorporated treatments, after the preparation of $10 \%$ GA, either imazalil at $0.2 \%$, potassium sorbate at $2 \%$ or potassium bicarbonate solution at $2 \%$ was added into GA, stirred for 30 min using magnetic stirrer and the $\mathrm{pH}$ of the solutions was adjusted to 5.6 with $1 \mathrm{~N} \mathrm{NaOH}$ using a digital $\mathrm{pH}$ meter. Five liter of distilled water without any additives was used to untreated fruits (control). Tween 80 was added to each the solution at a concentration of $0.05 \%$ $(\mathrm{v} / \mathrm{v})$ to improve wettability and adherence to 'Washington' navel oranges surface. Treatments for the experiment were as follow: distilled water and used for untreated fruits (control), IMZ at $0.2 \%$ and used as a commercial fungicide, GA at $10 \%, \mathrm{PS}$ at $2 \%, \mathrm{~PB}$ at $2 \%$, GA at $10 \%$ incorporated

Egypt. J. Hort. Vol. 45, No.2 (2018) 
with IMZ at $0.2 \%$, GA at $10 \%$ incorporated with PS at $2 \%$ and GA at $10 \%$ incorporated with PB at $2 \%$. These treatments were performed by soaking 'Washington' navel oranges in these solutions for three minutes. After soaking treatment, orange fruits were allowed to dry for one hour at room temperature by electric fan. All orange fruits in each treatment were packed in cardboard boxes with dimensions of $45 \times 35 \times 10 \mathrm{~cm}$ covered with polyethylene plastic films with a thickness of 0.04 $\mathrm{mm}$, five holes of $7 \mathrm{~mm}$ in diameter were made in the plastic film. Each treatment consisted of 126 fruits and each replicate contained of seven orange fruits for each storage period. All experimental boxes were stored at $5 \pm 1{ }^{\circ} \mathrm{C}$ and $90 \pm 5 \% \mathrm{RH}$ for ten weeks. Samples of oranges were taken at zero and every two weeks intervals of cold storage period at $5^{\circ} \mathrm{C}$ followed by seven days at ambient conditions $\left(18-23^{\circ} \mathrm{C}\right.$ and $\left.55 \pm 5 \% \mathrm{RH}\right)$ as a shelf life period to examine the effect of postharvest treatments and storage periods on decay incidence and measure the changes in physical and chemical attributes. Whereas, total phenolic content and total antioxidant capacity of orange fruits were determined at zero, two, six and ten weeks of cold storage period at $5^{\circ} \mathrm{C}$ followed by seven days shelf life at room temperature.

Measurement of fruit weight loss, decay and marketable percentage

Fruit weight loss percentage: it was calculated by the following formula: [(fruit weight before storage - fruit weight after each period of storage) / fruit weight before storage] $\times 100$.

Fruit decay percentage: it was recorded by the number of decayed fruits due to fungus and any micro-organisms infection and calculated as a percentage of the initial number of stored fruits using the following equation: (number of decayed fruits after each storage period / initial number of stored fruits) $\times 100$.

Fruit decay severity: it was determined as the diameter of the lesion surface $(\mathrm{mm})$ of orange fruits.

Marketable fruit percentage was calculated by the following formula: (weight of sound fruits after special storage period / initial weight of fruits) $\times 100$.

\section{Measurement of fruit visual appearance and firmness}

Fruit visual appearance was measured by a rating system and fruit was scored as very good $=9, \operatorname{good}=7$, acceptable $=5$, unacceptable $=3$ and poor $=1$

Egypt. J. Hort. Vol. 45, No.2 (2018)
Fruit firmness was measured in three orange fruits per replication at two equatorial sites to determine the penetration force by using a hand-held fruit firmness tester (FT-327, Italy) equipped with an $8 \mathrm{~mm}$ cylindrical stainless steel plunger tip (Watkins and Harman, 1981). Two readings were taken of each fruit after removing outer layer of peel. The firmness value was expressed in terms of kilogram force (kgf) and data was calculated as Newton (N) by the following formula ( $1 \mathrm{~N}=0.1 \mathrm{kgf})$.

Measurement of fruit juice, ascorbic acid (AsA), total soluble solids (TSS), titratable acidity (TA) contents and TSS/TA ratio in pulp

After each of storage period, nine orange fruits from each treatment (three replicates) were extracted by using a rotary extractor and then juice percentage $(\mathrm{w} / \mathrm{w})$ was calculated.

Fruit AsA analysis was determined according to AOAC (2005). Samples of fruit juice were used, oxalic acid solution was added to each sample and titrated with 2,6-dichlorophenol-indophenol dye solution and expressed as a milligram of AsA and was calculated as $\mathrm{mg} / 100 \mathrm{ml}$ juice.

Fruit TSS content was measured using a hand refractometer, 0-32 scale (ATAGO N-1 ${ }_{\mathrm{E}}$, Japan) and expressed in ${ }^{\circ}$ Brix after making the temperature correction at $20^{\circ} \mathrm{C}$ according to AOAC (2005).

Fruit TA was assayed based on the method of adopting the procedure described by AOAC (2005). Aliquot of fruit juice was taken and titrated against $0.1 \mathrm{~N} \mathrm{NaOH}$ in the presence of phenolphthalein as an indicator to the end point and expressed as a percentage of citric acid.

Fruit TSS/TA ratio was calculated from the values recorded for fruit juice TSS and TA percentages determined.

\section{Determination of total phenolic content (TPC)}

The TPC in the peel of oranges was spectrophotometrically determined by the FolinCiocalteu method (Slinkard and Singleton, 1977). Fruit samples were taken from six oranges (three replicates) at zero, two, six and ten weeks of cold storage period at $5^{\circ} \mathrm{C}$ followed by seven days shelf life. The absorbance against distilled water as a blank was determined at $765 \mathrm{~nm}$ by using a spectrophotometer (Thermo fisher 300 UV/VIS, USA). TPC was calculated from a standard curve obtained from different concentrations of gallic acid and expressed as mg of gallic acid equivalents/ gram fresh weight ( $g$ fw) for the peel extract. 


\section{Total antioxidant capacity (TAC) assay}

The TAC in the peel of orange fruits was determined according to the method of Prieto et al. (1999). Fruit samples were taken from six oranges at zero, two, six and ten weeks of cold storage period at $5^{\circ} \mathrm{C}$ followed by seven days shelf life. An aliquot of $0.5 \mathrm{ml}$ of the sample ethanolic solution (three replicates) was mixed with $3 \mathrm{ml}$ of the reagent solution $(0.6 \mathrm{M}$ sulfuric acid, 28 $\mathrm{mM}$ sodium phosphate and $4 \mathrm{mM}$ ammonium molybdate). For the blank, $0.5 \mathrm{ml}$ ethanol was mixed with $3 \mathrm{ml}$ of the reagent solution. The tubes of the samples and blank capped and were incubated in a water bath at $95^{\circ} \mathrm{C}$ for 90 minutes. After the samples had cooled to room temperature, the absorbance of the sample was measured at 695 $\mathrm{nm}$ against a blank by using a spectrophotometer (Thermo fisher 300 UV/VIS, USA). $\alpha$-Tocopherol was used for calibration curve and TAC was expressed as $\mathrm{mg}$ of $\alpha$-tocopherol equivalents per 100 gram of fresh weight ( $\mathrm{g} f w$ ) for the peel extract.

\section{Experimental design and statistical data analysis}

This experiment was arranged in a completely randomized design having three replicates and consisting of two factors, postharvest treatments and storage period. This experiment was analysis as factorial. Data calculated as percentage were transformed to arcsine of square root before statistical analysis and non-transformed means are shown. The effects of postharvest treatments and cold storage period on different attributes were analyzed statistically by analysis of variance (ANOVA) using the MSTAT-C statistical package (M-STAT, 1993). Comparisons between means were done by Duncan's multiple range test (DMRT) at probability $\leq 0.05$.

\section{Results and Discussion}

Effect of some postharvest dip treatments on physical characteristics of 'Washington' navel oranges during storage

Fruit weight loss, decay incidence, lesion diameter, marketable percentage and visual appearance score

Results in Tables 1, 2, 3, 4 and 5 reveal that weight loss, decay percentage and size of lesion surface diameter on 'Washington' navel oranges gradually and significantly increased with prolonging of cold storage period at $5^{\circ} \mathrm{C}$ followed by one week shelf life at $18-23^{\circ} \mathrm{C}$ in both seasons. On the other hand, navel oranges fruits showed gradual and significant reduction in marketable percentage and visual appearance score with the advancement of storage period during the two seasons. Our results indicate that, the significant maximum weight loss percentage $(14.45 \& 14.13$ $\%)$, decay incidence (15.91 \& $14.68 \%$ ) and size of lesion surface diameter (41.21 \& $40.46 \mathrm{~mm}$ ), moreover, the significant minimum marketable fruits percentage (69.65 \& $71.19 \%$ ) and visual appearance score $(5.42 \& 5.25)$ of oranges were observed at the end of storage period in the first and second seasons, respectively.

In addition, on the average, statistical data also demonstrate that, all postharvest treatments were significantly effective in reducing weight loss, decay percentage and size of lesion surface diameter with significant high in marketable fruit percentage and visual appearance of 'Washington' navel oranges as compared to control or treated fruits with imazalil in both seasons. Potassium sorbate or potassium bicarbonate incorporated into gum arabic was superior to either treatment alone or gum arabic incorporated with imazalil in this respect. Treatment of navel oranges with $10 \%$ gum arabic incorporated with $2 \%$ potassium sorbate and stored at $5^{\circ} \mathrm{C}$ followed by shelf life at $18-23^{\circ} \mathrm{C}$ recorded the significant lowest values of weight loss (4.43 \& $4.60 \%)$, decay incidence $(1.70 \& 1.63 \%)$ and lesion surface diameter (2.94 \& $2.72 \mathrm{~mm})$, furthermore recorded the significant highest values of marketable fruits (93.87\& $93.77 \%)$ and visual appearance score (8.67 \& 8.67) in the first and the second seasons, respectively followed by treated fruits with $10 \%$ gum arabic incorporated with $2 \%$ potassium bicarbonate. Conversely, control fruits exhibited the significant highest values of weight loss (12.28 \& $12.29 \%)$, decay incidence $(12.58 \&$ $11.49 \%)$ and lesion surface diameter (46.28 \& $45.67 \mathrm{~mm}$ ) with the significant lowest values of marketable fruits $(75.14 \& 76.23 \%)$ and visual appearance score (5.78 \& 5.78) in 2016 and 2017 seasons, respectively followed by treated oranges with $0.2 \%$ imazalil.

The interaction effect between postharvest treatments and storage periods showed significant differences at $p \leq 0.05$ for these characteristics in both seasons. Data declare that, postharvest treatment of oranges with $2 \%$ potassium sorbate incorporated with $10 \%$ gum arabic significantly delayed the decay incidence for six weeks at $5^{\circ} \mathrm{C}$ followed by one week shelf life at $18-23^{\circ} \mathrm{C}$ as compared to individual treatments and untreated fruits (control) in the two seasons. Our results 
indicate that, after the end of cold storage period followed by shelf life, postharvest treatment of orange fruits with $2 \%$ potassium sorbate incorporated with $10 \%$ gum arabic recorded the significant lowest values of weight loss percentage (8.81 \& $8.96 \%$ ), decay percentage $(7.07 \& 8.10 \%$ ) and lesion surface diameter $(11.33 \& 10.33 \mathrm{~mm})$, moreover recorded the significant highest values of marketable percentage $(84.12 \& 84.21 \%)$ and visual appearance score (8.00 $\& 8.00)$ in the first and second seasons, respectively. On the opposite, untreated fruits (control) showed the significant highest values of fruit weight loss percentage $(21.85 \& 21.24 \%)$, decay percentage $(29.16 \& 26.08 \%)$ and lesion surface diameter (108.67 \& $110.00 \mathrm{~mm}$ ) with recorded the significant lowest values of marketable fruits percentage (48.99 \& $52.68 \%)$ and visual appearance score $(2.33 \&$ 2.33 ) in 2016 and 2017 seasons, respectively.

The major cause in loss of visual quality for many citrus fruits is water loss whereby leading to economic losses for the industry and to undesirable effects such as shrinking, desiccated appearance, aging acceleration and loss firmness leading to the various rind disorders (Youssef et al., 2012a and Parra et al., 2014). Thus, the increasing in water loss and decay incidence with prolonging cold storage followed by shelf life due to an increase in water evaporation and aging of 'Washington' navel oranges.

Edible coatings have barrier properties that reduce the surface permeability of fruits to oxygen and carbon dioxide leading to modification of internal gas composition which in turn reduction of oxidative metabolism and increases the shelf life of fruits (Dhall, 2013). Thus, the application of gum arabic can reduce the exchange of gases between orange fruits and the environment by the accumulation of carbon dioxide in fruits and a low availability of oxygen for respiration and subsequently the inhibition of respiratory enzymes. Moreover, gum arabic coating it has ability to plug openings present in the peel. Furthermore, coating has the ability to prevent the growth of fungi in wide horticultural produces (Tripathi and Dubey, 2004).

In this study, gum arabic coating can form a film on the orange surface and this film acts as a fence to protect the fruits from pathogen infection, which reduced decay incidence during the storage and shelf life. In addition, sorbic acid seems to inhibit several enzymes such as fumarase, espartase and succinic dehydrogenase that involved in microorganism growth (York and Vaughn, 1964). Moreover, the antimicrobial activities for potassium sorbate and potassium bicarbonate are primarily due to the undissociated form of the acid, which is naturally more abundant at low $\mathrm{pH}$ (Davidson, 1997). The inhibitory ability of potassium sorbate and potassium bicarbonate depends on the presence of residues of these compounds within the wound infection courts occupied by the fungus and on interactions between this residue and constituents of the rind that preformed antifungal compounds (Palou et al., 2002).

TABLE 1. Effect of some postharvest dip treatments on weight loss percentage of 'Washington' navel oranges after cold storage at $5 \pm 1^{\circ} \mathrm{C}$ followed by one week shelf life at $18-23^{\circ} \mathrm{C}$

\begin{tabular}{|c|c|c|c|c|c|c|c|c|c|c|c|c|}
\hline \multirow{3}{*}{ Postharvest treatments } & \multicolumn{11}{|c|}{ Storage period (weeks) } & \\
\hline & & $\mathbf{0}$ & & 2 & 4 & & 6 & & & 8 & 10 & Means \\
\hline & \multicolumn{11}{|c|}{ Season 2016} & \\
\hline Distilled water (control) & 3.10 & $\mathrm{~s}-\mathrm{V}$ & 6.29 & $\mathrm{~m}-\mathrm{p}$ & 10.06 & hij & 14.34 & def & 18.05 & $\mathrm{~b}$ & 21.85 & $12.28 \mathrm{~A}$ \\
\hline $0.2 \%$ imazalil (IMZ) & 2.53 & $t-w$ & 5.01 & o-r & 7.46 & $\mathrm{klm}$ & 10.77 & hi & 13.75 & 5 def & 16.30 & $9.30 \mathrm{~B}$ \\
\hline $10 \%$ gum arabic $(\mathrm{GA})$ & 1.94 & $\mathrm{vw}$ & 3.90 & q-u & 6.06 & m-p & 9.05 & $\mathrm{ijk}$ & 12.65 & $5 \mathrm{fg}$ & $14.25 \mathrm{def}$ & $7.98 \mathrm{CD}$ \\
\hline $2 \%$ potassium sorbate $(\mathrm{PS})$ & 2.02 & $\mathrm{vw}$ & 4.20 & $q-\mathrm{t}$ & 6.34 & $\mathrm{~m}-\mathrm{p}$ & 9.56 & hij & 12.84 & fg & 14.75 cde & $8.29 \mathrm{CD}$ \\
\hline $2 \%$ potassium bicarbonate $(\mathrm{PB})$ & 2.16 & uvw & 4.68 & p-s & 6.71 & mno & 9.88 & hij & 13.01 & efg & $14.85 \mathrm{~cd}$ & $8.55 \mathrm{C}$ \\
\hline $10 \%$ GA incorporated with $0.2 \% \mathrm{IMZ}$ & 1.84 & $\mathrm{vw}$ & 3.87 & q-u & 6.05 & $\mathrm{~m}-\mathrm{p}$ & 8.92 & $\mathrm{jk}$ & 11.30 & gh & $13.90 \mathrm{def}$ & 7.65 \\
\hline $10 \%$ GA incorporated with $2 \%$ PS & 0.72 & $\mathrm{w}$ & 1.43 & vw & 3.21 & $\mathrm{r}-\mathrm{v}$ & 5.30 & $\mathrm{n}-\mathrm{q}$ & 7.14 & $\operatorname{lmn}$ & $8.81 \mathrm{jkl}$ & 4.43 \\
\hline $10 \%$ GA incorporated with $2 \% \mathrm{~PB}$ & 1.18 & w & 2.10 & uvw & 4.09 & $\mathrm{q}-\mathrm{t}$ & 6.94 & $\mathrm{mn}$ & 9.27 & $\mathrm{ij}$ & $10.85 \mathrm{hi}$ & 5.74 \\
\hline \multirow[t]{2}{*}{ Means } & 1.94 & $\mathrm{~F}$ & 3.94 & $\mathrm{E}$ & 6.25 & $\mathrm{D}$ & 9.35 & $\mathrm{C}$ & 12.25 & $\mathrm{~B}$ & $14.45 \mathrm{~A}$ & \\
\hline & \multicolumn{11}{|c|}{ Season 2017} & \\
\hline Distilled water (control) & 2.96 & uvw & 5.64 & $\mathrm{pq}$ & 10.23 & $\mathrm{j}$ & 14.95 & d & 18.71 & $\mathrm{~b}$ & 21.24 & 12.29 \\
\hline $0.2 \%$ imazalil (IMZ) & 2.43 & vwx & 4.57 & qrs & 7.39 & $\mathrm{mn}$ & 10.66 & ij & 13.95 & def & 16.55 & 9.26 \\
\hline $10 \%$ gum arabic (GA) & 2.12 & $v-y$ & 4.02 & stu & 5.99 & op & 8.71 & $\mathrm{kl}$ & 11.87 & hi & $13.90 \mathrm{def}$ & 7.77 \\
\hline $2 \%$ potassium sorbate $(\mathrm{PS})$ & 2.22 & $v-y$ & 4.31 & rst & 6.11 & op & 9.76 & $\mathrm{jk}$ & 12.51 & gh & $14.01 \mathrm{de}$ & $8.15 \mathrm{CD}$ \\
\hline $2 \%$ potassium bicarbonate $(\mathrm{PB})$ & 2.28 & vwx & 4.48 & $q-t$ & 6.20 & nop & 9.77 & $\mathrm{jk}$ & 12.72 & fgh & $14.26 \mathrm{de}$ & $8.29 \mathrm{C}$ \\
\hline $10 \%$ GA incorporated with $0.2 \% \mathrm{IMZ}$ & 2.06 & $v-y$ & 2.45 & vwx & 5.63 & $\mathrm{pq}$ & 8.16 & $\operatorname{lm}$ & 10.81 & $\mathrm{ij}$ & $13.23 \mathrm{efg}$ & 7.06 \\
\hline $10 \%$ GA incorporated with 2\% PS & 0.93 & $\mathrm{y}$ & 1.83 & wxy & 3.26 & tuv & 5.54 & pqr & 7.08 & mno & $8.96 \mathrm{kl}$ & 4.60 \\
\hline $10 \%$ GA incorporated with $2 \%$ PB & 1.12 & xy & 2.21 & $v-y$ & 4.17 & stu & 6.96 & mno & 8.67 & $\mathrm{kl}$ & 10.93 & 5.68 \\
\hline Means & 2.02 & $\mathrm{~F}$ & 3.69 & E & 6.12 & $\mathrm{D}$ & 9.32 & $\mathrm{C}$ & 12.04 & B & $14.13 \mathrm{~A}$ & \\
\hline
\end{tabular}

Means followed by the same letters within postharvest treatments, storage periods and their interactions in each season are not significantly different at level $P \leq 0.05$ according to DMRT.

Egypt. J. Hort. Vol. 45, No.2 (2018) 
TABLE 2. Effect of some postharvest dip treatments on decay incidence (\%) of 'Washington' navel oranges after cod storage at $5 \pm 1^{\circ} \mathrm{C}$ followed by one week shelf life at $18-23^{\circ} \mathrm{C}$

\begin{tabular}{|c|c|c|c|c|c|c|c|c|c|c|c|c|c|}
\hline \multirow{3}{*}{ Postharvest treatments } & \multicolumn{12}{|c|}{ Storage period (weeks) } & \multirow{3}{*}{ Means } \\
\hline & \multicolumn{2}{|l|}{$\mathbf{0}$} & \multicolumn{2}{|c|}{2} & \multicolumn{2}{|c|}{4} & \multicolumn{2}{|c|}{6} & \multicolumn{2}{|c|}{8} & \multicolumn{2}{|c|}{10} & \\
\hline & \multicolumn{12}{|c|}{ Season 2016} & \\
\hline Distilled water (control) & 0.00 & $\mathrm{j}$ & 2.78 & ij & 6.45 & $f-i$ & 14.53 & $\mathrm{~cd}$ & 22.54 & $\mathrm{~b}$ & 29.16 & $\mathrm{a}$ & $12.58 \mathrm{~A}$ \\
\hline $0.2 \%$ imazalil (IMZ) & 0.00 & $\mathrm{j}$ & 0.00 & $\mathrm{j}$ & 3.76 & hij & 8.72 & $e-h$ & 16.23 & $\mathrm{c}$ & 23.25 & $\mathrm{~b}$ & 8.66 \\
\hline $10 \%$ gum arabic $(\mathrm{GA})$ & 0.00 & $\mathrm{j}$ & 0.00 & $\mathrm{j}$ & 0.00 & $\mathrm{j}$ & 3.61 & hij & 10.35 & def & 14.44 & $\mathrm{~cd}$ & 4.73 \\
\hline $2 \%$ potassium sorbate $(\mathrm{PS})$ & 0.00 & $\mathrm{j}$ & 0.00 & $\mathrm{j}$ & 0.00 & $\mathrm{j}$ & 3.76 & hij & 11.09 & def & 14.51 & $\mathrm{~cd}$ & 4.89 \\
\hline $2 \%$ potassium bicarbonate $(\mathrm{PB})$ & 0.00 & $\mathrm{j}$ & 0.00 & $\mathrm{j}$ & 3.27 & ij & 4.84 & $g-j$ & 11.01 & def & 17.44 & $\mathrm{c}$ & 6.09 \\
\hline $10 \%$ GA incorporated with $0.2 \%$ IMZ & 0.00 & $\mathrm{j}$ & 0.00 & $\mathrm{j}$ & 0.00 & $\mathrm{j}$ & 3.93 & $g-j$ & 8.97 & efg & 12.44 & cde & $4.22 \mathrm{CD}$ \\
\hline $10 \%$ GA incorporated with $2 \%$ PS & 0.00 & $\mathrm{j}$ & 0.00 & $\mathrm{j}$ & 0.00 & $\mathrm{j}$ & 0.00 & $\mathrm{j}$ & 3.13 & $\mathrm{ij}$ & 7.07 & $f-i$ & $1.70 \quad \mathrm{E}$ \\
\hline $10 \%$ GA incorporated with $2 \% \mathrm{~PB}$ & 0.00 & $\mathrm{j}$ & 0.00 & $\mathrm{j}$ & 0.00 & $\mathrm{j}$ & 2.68 & $\mathrm{ij}$ & 4.95 & $g-j$ & 8.93 & efg & $2.76 \mathrm{DE}$ \\
\hline \multirow[t]{2}{*}{ Means } & 0.00 & $\mathrm{E}$ & 0.35 & $\mathrm{DE}$ & 1.69 & $\mathrm{D}$ & 5.26 & $\mathrm{C}$ & 11.03 & $\mathrm{~B}$ & 15.91 & $\mathrm{~A}$ & \\
\hline & \multicolumn{12}{|c|}{ Season 2017} & \\
\hline Distilled water (control) & 0.00 & $\mathrm{k}$ & 2.84 & $\mathrm{jk}$ & 6.40 & g-j & 12.99 & $\mathrm{~cd}$ & 20.60 & $\mathrm{~b}$ & 26.08 & $\mathrm{a}$ & $11.49 \mathrm{~A}$ \\
\hline $0.2 \%$ imazalil (IMZ) & 0.00 & $\mathrm{k}$ & 0.00 & $\mathrm{k}$ & 4.89 & ij & 9.71 & d-h & 14.43 & $\mathrm{~cd}$ & 21.04 & $\mathrm{~b}$ & $8.35 \mathrm{~B}$ \\
\hline $10 \%$ gum arabic $(\mathrm{GA})$ & 0.00 & $\mathrm{k}$ & 0.00 & $\mathrm{k}$ & 0.00 & $\mathrm{k}$ & 4.67 & $\mathrm{ijk}$ & 10.71 & d-g & 13.77 & $\mathrm{~cd}$ & $4.86 \mathrm{CD}$ \\
\hline $2 \%$ potassium sorbate $(\mathrm{PS})$ & 0.00 & $\mathrm{k}$ & 0.00 & $\mathrm{k}$ & 0.00 & $\mathrm{k}$ & 4.89 & $\mathrm{ij}$ & 11.57 & $c-f$ & 14.37 & $\mathrm{~cd}$ & $5.14 \mathrm{CD}$ \\
\hline $2 \%$ potassium bicarbonate $(\mathrm{PB})$ & 0.00 & $\mathrm{k}$ & 0.00 & $\mathrm{k}$ & 0.00 & $\mathrm{k}$ & 5.41 & hij & 12.35 & cde & 16.07 & $\mathrm{c}$ & $5.64 \mathrm{C}$ \\
\hline $10 \%$ GA incorporated with $0.2 \% \mathrm{IMZ}$ & 0.00 & $\mathrm{k}$ & 0.00 & $\mathrm{k}$ & 0.00 & $\mathrm{k}$ & 3.28 & $\mathrm{ijk}$ & 8.04 & $e-i$ & 11.18 & def & 3.75 \\
\hline $10 \%$ GA incorporated with $2 \%$ PS & 0.00 & $\mathrm{k}$ & 0.00 & $\mathrm{k}$ & 0.00 & $\mathrm{k}$ & 0.00 & $\mathrm{k}$ & 2.95 & $\mathrm{jk}$ & 6.83 & $f-j$ & 1.63 \\
\hline $10 \% \mathrm{GA}$ incorporated with $2 \% \mathrm{~PB}$ & 0.00 & $\mathrm{k}$ & 0.00 & $\mathrm{k}$ & 0.00 & $\mathrm{k}$ & 0.00 & $\mathrm{k}$ & 4.16 & $\mathrm{ijk}$ & 8.10 & $e-i$ & 2.04 \\
\hline Means & 0.00 & $\mathrm{D}$ & 0.36 & $\mathrm{D}$ & 1.41 & $\mathrm{D}$ & 5.12 & $\mathrm{C}$ & 10.60 & $\mathrm{~B}$ & 14.68 & A & \\
\hline
\end{tabular}

Means followed by the same letters within postharvest treatments, storage periods and their interactions in each season are not significantly different at level $P \leq 0.05$ according to DMRT.

TABLE 3. Effect of some postharvest dip treatments on lesion surface diameter ( $\mathrm{mm})$ of 'Washington' navel oranges after cold storage at $5 \pm 1^{\circ} \mathrm{C}$ followed by one week shelf life at $18-23^{\circ} \mathrm{C}$

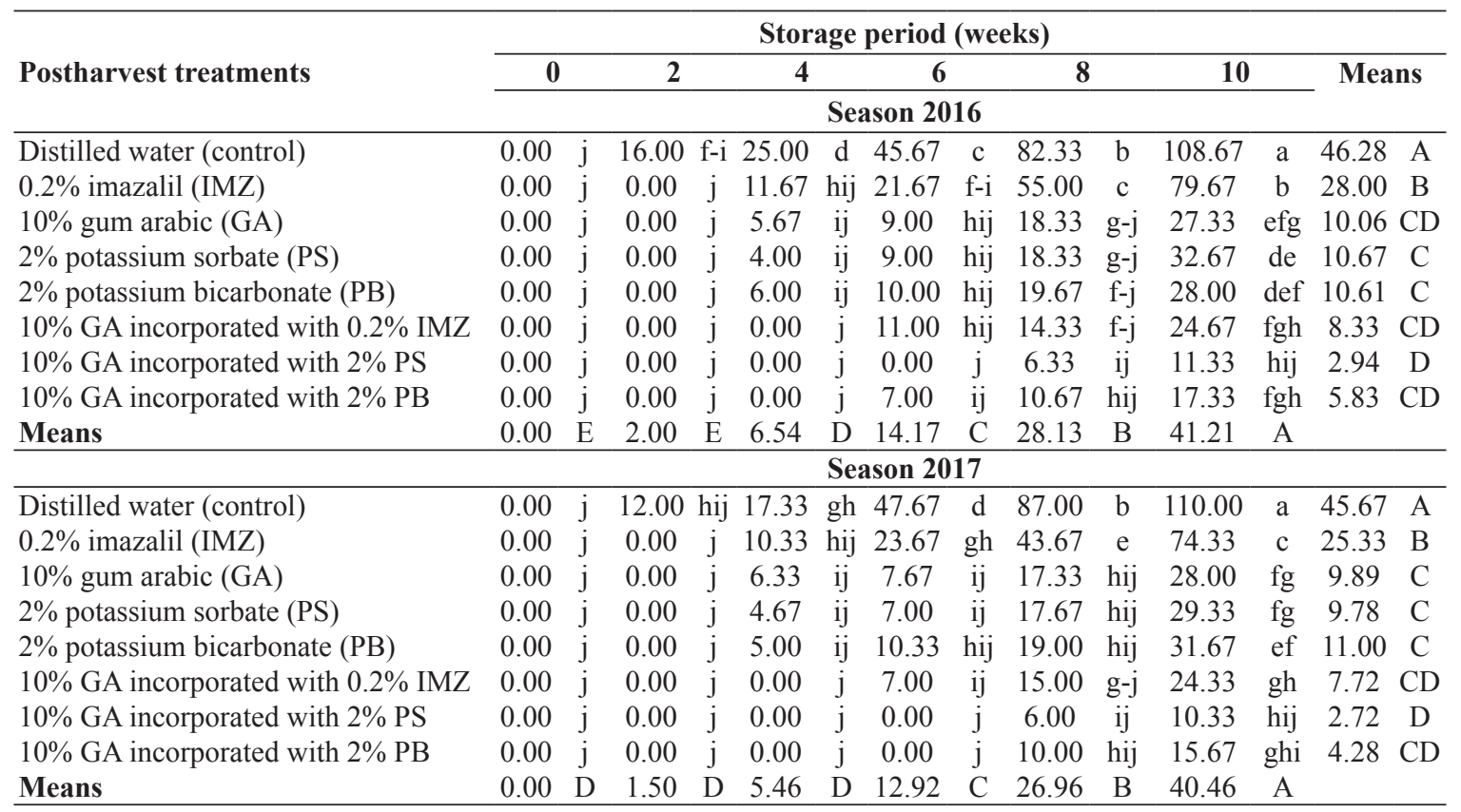

Means followed by the same letters within postharvest treatments, storage periods and their interactions in each season are not significantly different at level $P \leq 0.05$ according to DMRT. 
TABLE 4. Effect of some postharvest dip treatments on marketable percentage of 'Washington' navel oranges after cold storage at $5 \pm 1^{\circ} \mathrm{C}$ followed by one week shelf life at $18-23^{\circ} \mathrm{C}$

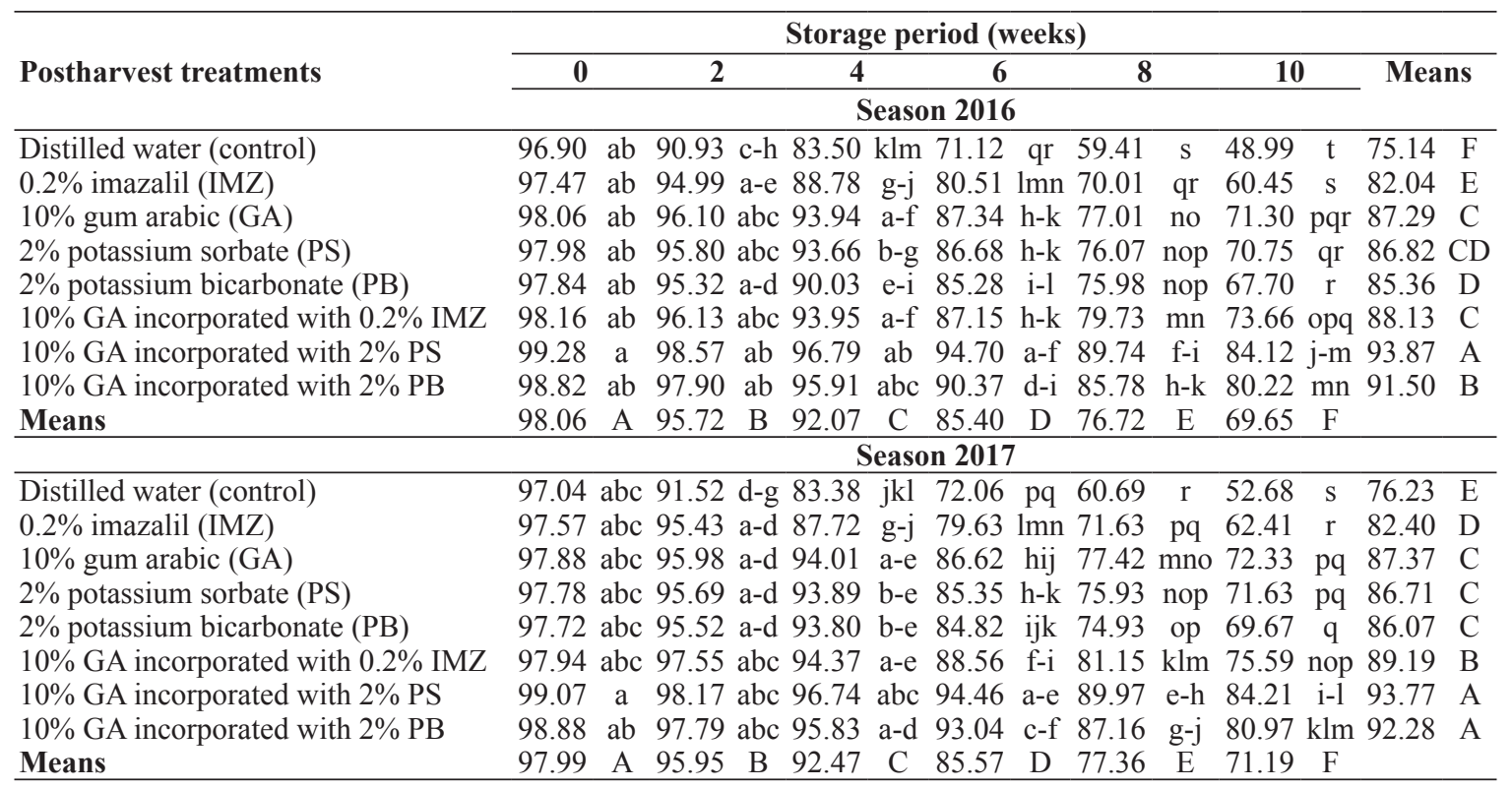

Means followed by the same letters within postharvest treatments, storage periods and their interactions in each season are not significantly different at level $P \leq 0.05$ according to DMRT.

The application of 'Washington' navel oranges with gum arabic coating especially incorporated with potassium sorbate or potassium bicarbonate causing a decrease in evapotranspiration and helped to delay fruits senescence because of slowing the metabolism and respiration rate. Moreover, the particularly low decay incidence for gum arabic coating incorporated with potassium sorbate or potassium bicarbonate treatment can be explained by the ability of this combination to inhibit molds by preformed antifungal compounds (Palou et al., 2008 and Montesinos-Herrero et al., 2009). A film of gum arabic on the orange surface can protect the fruits from pathogen infection. Moreover, potassium sorbate and bicarbonate provokes the collapse of hyphal cell walls and ultimately cell death (USEPA, 1998). In addition, potassium sorbate and potassium bicarbonate salts may have entered the wounds during infliction leading to an interaction between salt residues and constituents of oranges rind, thus creating unfavorable environmental conditions for the pathogen and possibly increasing tissue resistance (Youssef et al., 2012b and Youssef et al., 2014). Therefore, the reduction of decay incidence and lesion surface diameter of oranges by postharvest applications particularly potassium sorbate or potassium bicarbonate incorporated with gum arabic coating is probably due to the reduction of cell turgor pressure that caused collapse and shrinkage of hyphae and spores.

Furthermore, gum arabic coating enhanced retention of potassium sorbate or potassium bicarbonate on the oranges surface, which led to the higher antifungal effectiveness as compared to dipping oranges in aqueous solution alone. However, potassium sorbate and bicarbonate degraded by oxidation when used in aqueous solutions on food because of rapid reaction with food components (Scotter and Castle, 2004). Moreover, hydroxypropyl methylcellulose lipid edible composite coatings containing potassium sorbate, sodium benzoate and their mixtures were effective in reducing the development of green and blue moulds on 'Valencia' oranges (ValenciaChamorro et al., 2009). Therefore, when potassium sorbate or potassium bicarbonate added to gum arabic as an alternative to conventional chemical fungicide (imazalil) apparently did not alter the cosmetic properties of 'Washington' navel oranges, reduced weigh loss percentage, controlled decay incidence and decreased size of lesion surface diameter with an increase in the percent of marketable oranges and visual appearance score. 
TABLE 5. Effect of some postharvest dip treatments on visual appearance score of 'Washington' navel oranges after cold storage at $5 \pm 1^{\circ} \mathrm{C}$ followed by one week shelf life at $18-23^{\circ} \mathrm{C}$

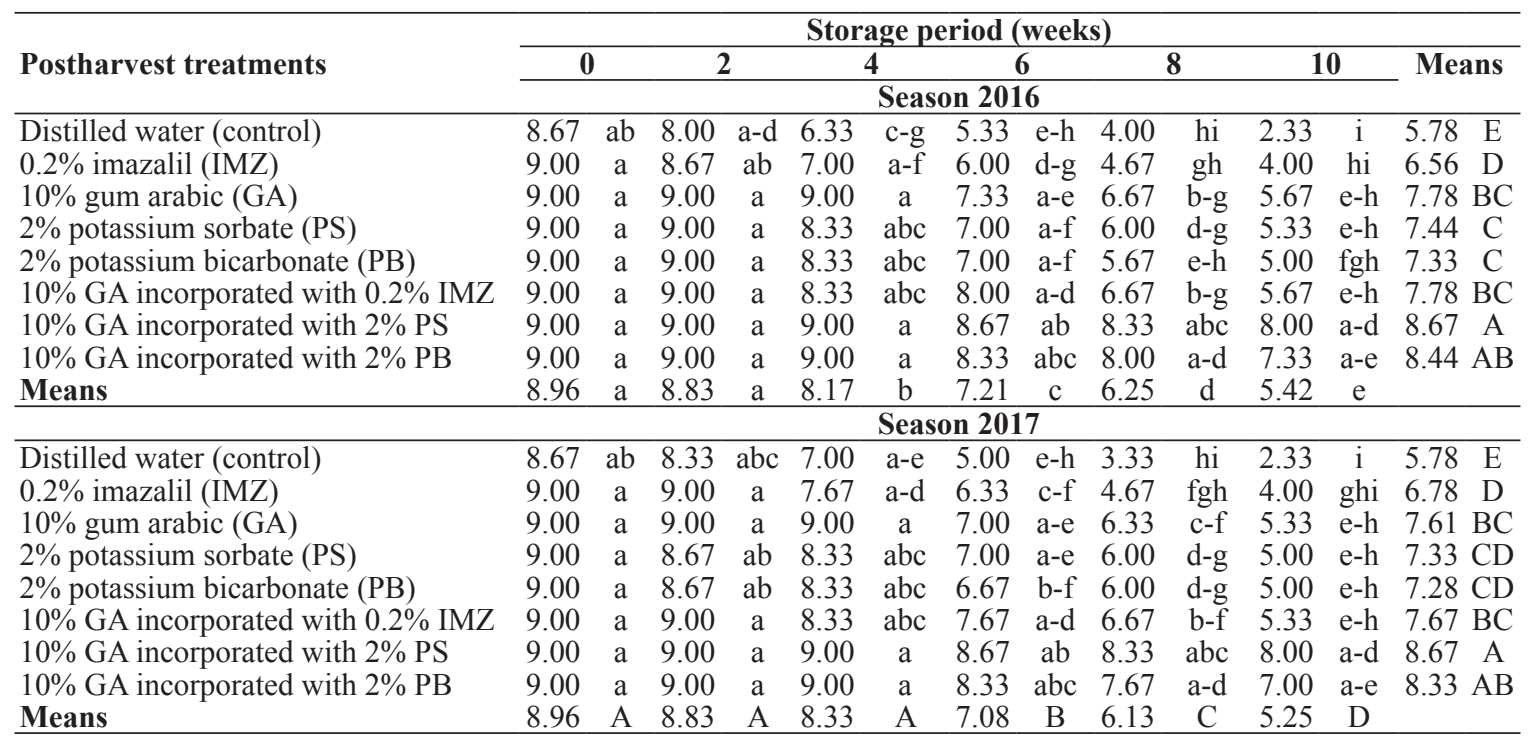

Means followed by the same letters within postharvest treatments, storage periods and their interactions in each season are not significantly different at level $P \leq 0.05$ according to DMRT.

The results are in agreement with the findings of previous research, which reported that weight loss and decay incidence were reduced with gum arabic coating in 'Choke Anan' mangoes (Khaliq et al., 2015), banana and papaya fruits (Maqbool et al., 2011) and 'Anna' apples (El-Anany et al., 2009). Moreover, the obtained results were similar to those mentioned by Palou et al. (2002), Smilanick et al. (2008), Montesinos-Herrero et al. (2009), Youssef et al. (2012a, b), Cerioni et al. (2013), Parra et al. (2014), Youssef et al. (2014) and Cerioni et al. (2017). They noted that citrus fruits treated with potassium sorbate or potassium bicarbonate significantly reduced weight loss percentage, postharvest decay incidence and lesion surface diameter without altering the visual appearance of fruits. Similarly, Palou et al. (2009) observed the same results when stone fruits treated with potassium bicarbonate solution.

\section{Fruit firmness}

Results in Table 6 show that, a gradual and significant decrease in 'Washington' navel oranges firmness was observed with prolonging of cold storage period at $5^{\circ} \mathrm{C}$ followed by one week shelf life at $18-23^{\circ} \mathrm{C}$ in the two seasons. Hence, the results indicate that, the significant minimum firmness of orange fruits was recorded at the end of cold storage period and the values reaches of $18.03 \& 18.60 \mathrm{~N}$ in the first and second seasons, respectively.

On the average, displayed results also prove that, all postharvest applications of 'Washington' navel oranges significantly reduced the deterioration of fruit firmness as compared to water control or treated oranges with imazalil after cold storage at $5^{\circ} \mathrm{C}$ followed by one week shelf life at $18-23^{\circ} \mathrm{C}$ in the two seasons. In this context, the co-application of gum arabic and either potassium sorbate or potassium bicarbonate was superior to either treatment alone or gum arabic incorporated with imazalil. Treatment of navel oranges with $2 \%$ potassium sorbate incorporated with $10 \%$ gum arabic recorded the significant highest values of fruit firmness $(34.72 \& 34.12 \mathrm{~N})$ in 2016 and 2017 seasons, respectively followed by treated navel oranges with $2 \%$ potassium bicarbonate incorporated with $10 \%$ gum arabic. On contrary, untreated fruits showed the significant lowest values of fruit firmness $(18.48 \& 19.73 \mathrm{~N})$ in the first and second seasons, respectively followed by treated oranges with $0.2 \%$ imazalil.

Referring to the interaction effect, there was a significant interaction between postharvest treatments and storage periods at $p \leq 0.05$ for firmness in both seasons. The results indicate that, after the end of cold storage period followed by shelf life, postharvest treatment of orange fruits with $2 \%$ potassium sorbate incorporated with $10 \%$ gum arabic had the significant highest firmness $(24.52 \& 25.83 \mathrm{~N})$ in the first and second seasons, respectively. On contrary, untreated fruits (control) had the significant lowest firmness (9.16 $\& 9.48$ N) in 2016 and 2017 seasons, respectively. 
TABLE 6. Effect of some postharvest dip treatments on firmness $(N)$ of 'Washington' navel oranges after cold storage at $5 \pm 1^{\circ} \mathrm{C}$ followed by one week shelf life at $18-23^{\circ} \mathrm{C}$

\begin{tabular}{|c|c|c|c|c|c|c|c|c|c|c|c|}
\hline \multirow{3}{*}{ Postharvest treatments } & \multicolumn{10}{|c|}{ Storage period (weeks) } & \multirow{3}{*}{ Means } \\
\hline & $\mathbf{0}$ & & 2 & 2 & 4 & 6 & 6 & 8 & & 10 & \\
\hline & \multicolumn{10}{|c|}{ Season 2016} & \\
\hline Distilled water (control) & 36.30 & fgh & 26.82 & $21-0$ & $15.37 \mathrm{tu}$ & 12.43 & 3 uv & 10.79 & $\mathrm{v}$ & 9.16 & $18.48 \mathrm{G}$ \\
\hline $0.2 \%$ imazalil (IMZ) & 38.91 & $a-f$ & 32.70 & $\mathrm{ij}$ & $26.16 \mathrm{mno}$ & 19.95 & 5 qrs & 16.68 & st & $15.37 \mathrm{tu}$ & 24.96 \\
\hline $10 \%$ gum arabic $(\mathrm{GA})$ & 41.53 & $\mathrm{ab}$ & 36.95 & $5 d-h$ & $31.39 \mathrm{jk}$ & 24.20 & nop & 18.97 & rst & $18.64 \mathrm{rst}$ & $28.61 \mathrm{D}$ \\
\hline $2 \%$ potassium sorbate $(\mathrm{PS})$ & 39.90 & $a-f$ & 36.63 & $3 e-h$ & 30.74 & 23.22 & 2 opq & 17.33 & st & $17.66 \mathrm{st}$ & $27.58 \mathrm{DE}$ \\
\hline te $(\mathrm{PB})$ & 40.22 & a-e & 36.63 & $3 \mathrm{e}-\mathrm{h}$ & 30.08 & 21.91 & 1 pqr & 17.01 & st & $16.68 \mathrm{st}$ & $27.09 \mathrm{E}$ \\
\hline $10 \%$ GA incorporated with $0.2 \% \mathrm{IMZ}$ & 40.88 & $a b c$ & 37.28 & $\mathrm{c}-\mathrm{h}$ & 34.99 ghi & 27.14 & $4 \operatorname{lmn}$ & 23.54 & $n-q$ & $20.27 \mathrm{qrs}$ & 30.68 \\
\hline $10 \%$ GA incorporated with $2 \%$ PS & 42.51 & $\mathrm{a}$ & 40.55 & 5 a-d & 38.59 b-g & 33.68 & 3 hij & 28.45 & $\mathrm{klm}$ & 24.52 nop & 34.72 \\
\hline $10 \%$ GA incorporatec & 41.53 & $\mathrm{ab}$ & 38.59 & b-g & $36.62 \mathrm{e}-\mathrm{h}$ & 32.05 & & 24.53 & nop & $21.91 \mathrm{pqr}$ & $32.54 \mathrm{~B}$ \\
\hline \multirow[t]{2}{*}{ Means } & 40.22 & A & 35.77 & $7 \mathrm{~B}$ & $30.49 \mathrm{C}$ & 24.32 & $\mathrm{D}$ & 19.66 & E & $18.03 \mathrm{~F}$ & \\
\hline & \multicolumn{10}{|c|}{ Season 2017} & \\
\hline Distilled $\mathrm{w}$ & 36.62 & $\mathrm{e}$ & 26.16 & $5 \operatorname{lm}$ & 17.99 rst & 15.37 & $7 \mathrm{stu}$ & 12.75 & $\mathrm{u}$ & 9.48 & 19.73 \\
\hline & 38.91 & b-e & 33.68 & $\mathrm{f}$ & $26.49 \mathrm{~lm}$ & 24.20 & $\mathrm{mn}$ & 18.31 & qrs & 15.04 tu & 26.10 \\
\hline $10 \%$ gum arabic $(\mathrm{GA})$ & 41.53 & $\mathrm{ab}$ & 37.28 & $\mathrm{e}$ & $31.07 \mathrm{fgh}$ & 27.80 & $i-1$ & 22.23 & nop & 19.62 o-r & $29.92 \mathrm{C}$ \\
\hline $2 \%$ potassium sorbate $(\mathrm{PS})$ & 41.20 & $\mathrm{ab}$ & 36.95 & $\mathrm{e}$ & $30.74 \mathrm{f}-\mathrm{i}$ & 27.14 & $4 \mathrm{klm}$ & 21.26 & $n-q$ & $17.98 \mathrm{rst}$ & $29.21 \mathrm{CD}$ \\
\hline $2 \%$ potassium bicarbonate $(\mathrm{PB})$ & 40.55 & $a-d$ & 36.63 & $\mathrm{e}$ & $30.41 g-j$ & 25.83 & $3 \operatorname{lm}$ & 19.29 & pqr & $17.66 \mathrm{rst}$ & $28.40 \mathrm{D}$ \\
\hline $10 \%$ GA incorporated with $0.2 \% \mathrm{IMZ}$ & 40.87 & $a b c$ & 37.61 & de & 32.37 & 28.12 & $2 \mathrm{~h}-1$ & 28.12 & $h-1$ & 20.60 o-r & $31.28 \mathrm{~B}$ \\
\hline $10 \%$ GA incorporated $\mathrm{v}$ & 43.49 & $\mathrm{a}$ & 39.24 & 4 b-e & 33.68 & 32.04 & $4 \mathrm{fg}$ & 30.41 & $g-j$ & $25.83 \mathrm{~lm}$ & 34.12 \\
\hline $10 \%$ GA incorporated with $2 \% \mathrm{~PB}$ & 41.85 & $a b$ & 37.93 & 3 cde & 32.70 & 30.08 & g-k & 27.47 & $\mathrm{jkl}$ & 22.56 no & $32.10 \mathrm{~B}$ \\
\hline Means & 40.63 & A & 35.69 & $\mathrm{~B}$ & $29.43 \mathrm{C}$ & 26.32 & $2 \mathrm{D}$ & 22.48 & $\mathrm{E}$ & $18.60 \mathrm{~F}$ & \\
\hline
\end{tabular}

Means followed by the same letters within postharvest treatments, storage periods and their interactions in each season are not significantly different at level $P \leq 0.05$ according to DMRT.

Fruit softening is one the most important quality deterioration parameters during postharvest storage. Fruit softening attributed to biochemical processes involving the hydrolysis of pectin in the cell wall by hydrolytic enzymes such as pectinesterase, pectin methylesterase and polygalacturonase (Payasi et al., 2009). Our results in the current study indicated that, firmness retention in coated oranges by gum arabic incorporated with potassium sorbate or potassium bicarbonate is related to a reduction in enzymatic activities involved in softening process. Also, related to their ability to control weight loss caused by a modification of the internal atmosphere of the fruit as documented by Khaliq et al. (2015). In addition, dramatic drop in the firmness after cold storage followed by shelf life of 'Washington' navel oranges could be attributed to the increase in weight loss rate and conversion of insoluble protopectin into water soluble pectin.

These results are in agreement with those obtained by Maqbool et al. (2011) in banana and papaya fruits and Khaliq et al. (2015) in 'Choke Anan' mangoes they reported that, treated fruits with edible coatings of gum arabic significantly higher firmness than uncoated fruits during cold storage and shelf life.
Effect of some postharvest dip treatments on chemical characteristics of 'Washington' navel oranges during storage

Fruit juice percentage, ascorbic acid (AsA), total soluble solids (TSS), titratable acidity (TA) and TSS/TA ratio

Changes in juice, AsA, TSS, TA contents and TSS/TA ratio of 'Washington' navel oranges after cold storage period at $5^{\circ} \mathrm{C}$ followed by one week shelf life at $18-23^{\circ} \mathrm{C}$ are shown in Tables $7,8,9,10$ and 11 . Results illustrate that, significant declining trend in juice, ascorbic acid and TA contents were noticed with prolonging of cold storage period in the first and second seasons. While, significant rising trend in TSS and TSS/TA ratio were observed with the advancement of storage period in the both seasons. Also, results reveal that, the significant lowest of fruits juice percentage (31.18 \& $30.49 \%$ ), AsA content (38.51 \& $37.81 \mathrm{mg} / 100$ $\mathrm{ml}$ juice) and TA percentage (0.52 \& $0.54 \%)$, furthermore the significant highest of TSS (12.24 $\& 12.23{ }^{\circ}$ Brix) and TSS/TA ratio (24.60 \& 24.31) in the first and second seasons, respectively were noticed after the end of storage period.

In addition, on the average also results reveal that, all postharvest dip treatments of orange fruits significantly increased juice percentage, 
AsA content and TA as compared to water control or treated fruits with imazalil in both seasons. Moreover, non-significant differences of juice percentage and AsA content were observed when treated oranges with gum arabic, potassium sorbate or potassium bicarbonate individually in the two seasons. In addition, treatment of navel oranges with gum arabic alone or incorporated with potassium sorbate or potassium bicarbonate significantly slowed the rate of increase of TSS content than control or individual treatment of potassium sorbate and potassium bicarbonate in both seasons. Furthermore, all postharvest treatments especially co-applications were significantly effective in reducing TSS/TA ratio of navel oranges as compared to the water control or treated oranges with imazalil during the two seasons. Data also clearly indicate that, postharvest treatment of 'Washington' navel oranges with 2\% potassium sorbate incorporated with $10 \%$ gum arabic showed the significant highest of juice percentage $(42.33 \&$ $44.24 \%)$, AsA content (59.85 \& $58.31 \mathrm{mg} / 100 \mathrm{ml}$ juice) and TA percentage ( $0.85 \& 0.92 \%)$, whereas, recorded the significant lowest of TSS $(9.97 \&$ $10.11^{\circ}$ Brix) and TSS/TA ratio (12.31 \& 11.44) in the first and second seasons, respectively followed by treated oranges with $2 \%$ potassium bicarbonate and incorporated with 10\% gum arabic. Conversely, untreated fruits had the significant lowest juice percentage (33.36 \& $33.75 \%)$, AsA content (45.87 $\& 44.03 \mathrm{mg} / 100 \mathrm{ml}$ juice) and TA percentage ( 0.61 \& $0.68 \%$ ), moreover had the significant highest TSS (10.76 \& $11.02^{\circ}$ Brix) and TSS/TA ratio (19.57 \& 18.25) in 2016 and 2017 seasons, respectively followed by treated oranges with $0.2 \%$ imazalil.

Data also declare that, there was a significant interaction among postharvest treatments and storage periods at $p \leq 0.05$ for these characteristics in the two seasons. Our results indicate that, after the end of cold storage period followed by shelf life, postharvest treatment of orange fruits with $2 \%$ potassium sorbate incorporated with $10 \%$ gum arabic had the significant highest of juice percentage (37.24 \& $36.29 \%)$, AsA content (47.74 \& $47.05 \mathrm{mg} / 100 \mathrm{ml}$ juice) and TA percentage $(0.68 \& 0.79 \%)$, whereas recorded the significant lowest of TSS (11.67 \& $11.60{ }^{\circ}$ Brix) and TSS/TA ratio (17.70 \& 15.61) in the first and second seasons, respectively. On contrary, untreated fruits (control) recorded the significant lowest of juice percentage (23.17 \& $22.23 \%)$, AsA content (27.16 $\& 26.10 \mathrm{mg} / 100 \mathrm{ml}$ juice) and TA percentage ( 0.41 \& $0.41 \%$ ), while recorded the significant highest of TSS (12.53 \& $12.47^{\circ}$ Brix) and TSS/TA ratio (30.97 $\& 30.82$ ) in 2016 and 2017 seasons, respectively.

Maintaining juice percentage in treated 'Washington' navel oranges with gum arabic incorporated with potassium sorbate or potassium bicarbonate coating is probably due to the reduction of water loss from the fruits as compared to other treated fruits. Moreover, a progressive decline in juice content after cold storage period followed by shelf life attributed to an increase in water loss from oranges.

Ascorbic acid was considered as antioxidant and play important role in reducing the oxidative damage of fruits caused by reactive oxygen species. The reduction of AsA loss in coated 'Washington' navel oranges with gum arabic incorporated with potassium bicarbonate or potassium bicarbonate was proposed to be due to the low oxygen permeability around fruit surface and restraining the physiological activities by delaying ageing of oranges. Lowered oxygen level resulted in a slow down of the respiration rate and reduced the activity of the ascorbic acid oxidase enzymes (Blokhina et al., 2003). Thus, our results in this study indicated that, potassium sorbate or potassium bicarbonate incorporated into gum arabic preventing the oxidation of AsA of oranges as compared to water control or treated fruits with imazalil as mentioned by Liu et al. (2014) and Khaliq et al. (2015). In addition, the loss of ascorbic acid content of 'Washington' navel oranges during storage period followed by shelf life might be due to rapid conversion of L-ascorbic acid into dehydroascorbic acid in the presence of oxidizing enzymes like ascorbic acid oxidase and ascorbate peroxidase (Mapson, 1970).

TSS and TA are two main components that greatly influence flavor properties of citrus fruits. Edible coatings created an excellent semi-permeable film around the fruit and modifying the internal atmosphere by reducing oxygen and elevating carbon dioxide resulting in decreased respiration rate (Dhall, 2013). In the present study, coated 'Washington' navel oranges with gum arabic incorporated with potassium sorbate or potassium bicarbonate showed delay the rate of increase of TSS and TSS/TA ratio with high level of TA, which means that this treatment might be maintained the organic acid by reduction of respiration rate, metabolic activity and inhibited oxidation of organic acid. Thus, protected the degradation of organic acids and clearly delayed the decrease in TA as documented by Khaliq et al. (2015) in this respect. While the highest TSS values in other treatments of oranges maybe attributed to the loss of water and increasing metabolic activity of fruits. In water control or treated orange fruits with imazalil, the high reduction in TA might be resulted from increased respiration rate that caused degeneration of organic acids (El-Anany et al., 2009). Citric acid is the major organic acid in citrus fruits. The reduction in TA after cold storage followed by shelf life might be attributed to the use of organic acids as substrates for respiratory metabolism in fruits and conversion of acids into salts and sugars by the enzymes (Valero and Serrano, 2010). 
TABLE 7. Effect of some postharvest dip treatments on juice percentage of 'Washington' navel oranges after cold storage at $5 \pm 1^{\circ} \mathrm{C}$ followed by one week shelf life at $18-23^{\circ} \mathrm{C}$

\begin{tabular}{|c|c|c|c|c|c|c|c|c|c|c|c|c|c|}
\hline \multirow{3}{*}{ Postharvest treatments } & \multicolumn{12}{|c|}{ Storage period (weeks) } & \multirow{3}{*}{ Means } \\
\hline & $\mathbf{0}$ & & 2 & & 4 & & 6 & & 8 & 8 & 10 & $\mathbf{0}$ & \\
\hline & \multicolumn{12}{|c|}{ Season 2016} & \\
\hline Distilled water (control) & 43.50 & $b-f$ & 38.87 & i-o & 35.25 & $\mathrm{p}-\mathrm{s}$ & 32.22 & st & 27.16 & $\mathrm{v}$ & 23.17 & $\mathrm{w}$ & $33.36 \mathrm{E}$ \\
\hline $0.2 \%$ imazalil (IMZ) & 42.25 & $\mathrm{~d}-\mathrm{h}$ & 41.98 & $d-\mathrm{i}$ & 37.52 & $1-p$ & 35.14 & $\mathrm{p}-\mathrm{s}$ & 32.58 & st & 28.56 & 5 uv & $36.34 \mathrm{D}$ \\
\hline $10 \%$ gum arabic $(\mathrm{GA})$ & 44.73 & $a-d$ & 43.30 & $c-f$ & 39.34 & $h-n$ & 38.02 & $k-p$ & 36.23 & $3 n-r$ & 32.23 & st & $38.98 \mathrm{C}$ \\
\hline $2 \%$ potassium sorbate $(\mathrm{PS})$ & 44.09 & b-e & 43.67 & b-e & 38.72 & $\mathrm{j}-\mathrm{o}$ & 37.45 & $1-\mathrm{p}$ & 35.69 & o-r & 31.03 & tu & $38.44 \mathrm{C}$ \\
\hline $2 \%$ potassium bicarbonate $(\mathrm{PB})$ & 43.87 & b-e & 42.79 & $\mathrm{c}-\mathrm{g}$ & 38.35 & $j-p$ & 36.91 & m-r & 35.90 & o-r & 29.06 & 5 uv & $37.81 \mathrm{C}$ \\
\hline $10 \%$ GA incorporated with $0.2 \% \mathrm{IMZ}$ & 46.71 & $\mathrm{ab}$ & 44.27 & b-e & 40.95 & e-k & 39.91 & g-m & 37.74 & 4 k-p & 33.99 & rst & $40.60 \mathrm{~B}$ \\
\hline $10 \%$ GA incorporated with $2 \%$ PS & 47.46 & $\mathrm{a}$ & 46.08 & $a b c$ & 44.24 & b-e & 41.30 & $e-j$ & 37.67 & $71-p$ & 37.24 & $1-q$ & $42.33 \mathrm{~A}$ \\
\hline $10 \%$ GA incorporated with $2 \%$ PB & 45.08 & $a-d$ & 44.09 & b-e & 42.31 & d-h & 40.28 & $f-1$ & 37.90 & k-p & 34.18 & qrs & $40.64 \mathrm{~B}$ \\
\hline \multirow[t]{2}{*}{ Means } & 44.71 & A & 43.13 & $\mathrm{~B}$ & 39.59 & $\mathrm{C}$ & 37.65 & $\mathrm{D}$ & 35.11 & $\mathrm{E}$ & 31.18 & $\mathrm{~F}$ & \\
\hline & \multicolumn{12}{|c|}{ Season 2017} & \\
\hline Distilled water (control) & 47.19 & b-e & 40.79 & i-1 & 34.35 & $\mathrm{p}$ & 30.46 & rst & 27.48 & 3 uv & 22.23 & $\mathrm{w}$ & $33.75 \mathrm{~F}$ \\
\hline $0.2 \%$ imazalil (IMZ) & 47.57 & $a-d$ & 42.11 & h-k & 38.02 & $1-0$ & 33.01 & $\mathrm{p}-\mathrm{s}$ & 31.18 & $8 \mathrm{q}-\mathrm{t}$ & 26.98 & $\mathrm{v}$ & $36.48 \mathrm{E}$ \\
\hline $10 \%$ gum arabic $(\mathrm{GA})$ & 48.85 & $a-d$ & 44.47 & $e-h$ & 39.73 & $\mathrm{kl}$ & 35.01 & op & 35.16 & 6 nop & 30.57 & $7 \mathrm{rst}$ & $38.97 \mathrm{D}$ \\
\hline $2 \%$ potassium sorbate $(\mathrm{PS})$ & 47.88 & $a-d$ & 43.87 & $\mathrm{f}-\mathrm{i}$ & 39.24 & $\mathrm{klm}$ & 34.80 & $\mathrm{p}$ & 34.21 & $1 \mathrm{pq}$ & 29.51 & tuv & $38.25 \mathrm{D}$ \\
\hline $2 \%$ potassium bicarbonate $(\mathrm{PB})$ & 47.22 & b-e & 42.87 & $g-j$ & 38.52 & $\operatorname{lm}$ & 34.18 & $\mathrm{pq}$ & 34.22 & $2 \mathrm{pq}$ & 30.12 & stu & $37.86 \mathrm{D}$ \\
\hline $10 \%$ GA incorporated with $0.2 \% \mathrm{IMZ}$ & 49.25 & $\mathrm{abc}$ & 46.12 & $c-f$ & 42.97 & $g-j$ & 38.59 & $\operatorname{lm}$ & 36.22 & $2 \mathrm{~m}-\mathrm{p}$ & 33.27 & pqr & $41.07 \mathrm{C}$ \\
\hline $10 \%$ GA incorporated with $2 \%$ PS & 50.66 & $\mathrm{a}$ & 49.85 & $a b$ & 45.78 & d-g & 42.92 & $g-j$ & 39.94 & $4 \mathrm{jkl}$ & 36.29 & $m-p$ & $44.24 \mathrm{~A}$ \\
\hline $10 \%$ GA incorporated with $2 \% \mathrm{~PB}$ & 49.77 & $a b$ & 48.13 & $\mathrm{a}-\mathrm{d}$ & 44.17 & $e-h$ & 40.60 & $\mathrm{jkl}$ & 38.19 & $9 \mathrm{lmn}$ & 34.92 & $\mathrm{p}$ & $42.63 \mathrm{~B}$ \\
\hline Means & 48.55 & A & 44.78 & B & 40.35 & $\mathrm{C}$ & 36.20 & $\mathrm{D}$ & 34.58 & E & 30.49 & $\mathrm{~F}$ & \\
\hline
\end{tabular}

Means followed by the same letters within postharvest treatments, storage periods and their interactions in each season are not significantly different at level $P \leq 0.05$ according to DMRT.

TABLE 8. Effect of some postharvest dip treatments on ascorbic acid content (mg/100 ml juice) of 'Washington' navel oranges after cold storage at $5 \pm 1^{\circ} \mathrm{C}$ followed by one week shelf life at $18-23^{\circ} \mathrm{C}$

\begin{tabular}{|c|c|c|c|c|c|c|c|c|c|c|c|c|}
\hline \multirow{3}{*}{ Postharvest treatments } & \multicolumn{11}{|c|}{ Storage period (weeks) } & \multirow{3}{*}{ Means } \\
\hline & $\mathbf{0}$ & & 2 & & 4 & & 6 & & 8 & & 10 & \\
\hline & \multicolumn{11}{|c|}{ Season 2016} & \\
\hline Distilled water (control) & 65.72 & $\mathrm{c}-\mathrm{f}$ & 59.05 & hi & 48.76 & $\operatorname{lm}$ & 40.15 & $\mathrm{qr}$ & 34.40 & $\mathrm{u}$ & 27.16 & 45.87 \\
\hline $0.2 \%$ imazalil (IMZ) & 67.66 & bcd & 62.93 & fg & 54.88 & $\mathrm{jk}$ & 47.56 & $\mathrm{mn}$ & 40.24 & $\mathrm{qr}$ & 34.96 tu & 51.37 \\
\hline $10 \%$ gum arabic $(\mathrm{GA})$ & 68.66 & $\mathrm{abc}$ & 64.37 & d-g & 58.91 & hi & 51.63 & 1 & 43.49 & opq & $38.62 \mathrm{rs}$ & $54.28 \mathrm{CD}$ \\
\hline $2 \%$ potassium sorbate $(\mathrm{PS})$ & 68.41 & $\mathrm{bc}$ & 64.08 & efg & 58.91 & hi & 50.41 & $\operatorname{lm}$ & 42.68 & opq & $37.80 \mathrm{rst}$ & $53.71 \mathrm{CD}$ \\
\hline $2 \%$ potassium bicarbonate $(\mathrm{PB})$ & 68.16 & bc & 63.50 & fg & 58.05 & hij & 50.00 & $\operatorname{lm}$ & 42.27 & 7 opq & $35.77 \mathrm{stu}$ & $52.96 \mathrm{D}$ \\
\hline $10 \% \mathrm{GA}$ incorporated with $0.2 \% \mathrm{IMZ}$ & 69.52 & $a b$ & 65.24 & $c-f$ & 57.71 & hij & 52.27 & $\mathrm{kl}$ & 44.28 & op & $41.16 \mathrm{pqr}$ & 55.03 \\
\hline $10 \%$ GA incorporated with 2\% PS & 71.91 & $\mathrm{a}$ & 68.09 & bc & 63.19 & fg & 57.58 & $\mathrm{ij}$ & 50.61 & $\operatorname{lm}$ & $47.74 \mathrm{mn}$ & 59.85 \\
\hline $10 \%$ GA incorporated with $2 \%$ PB & 70.48 & $a b$ & 67.14 & b-e & 61.19 & gh & 55.30 & $\mathrm{jk}$ & 49.03 & $\operatorname{lm}$ & 44.85 no & $58.00 \mathrm{~B}$ \\
\hline \multirow[t]{2}{*}{ Means } & 68.81 & $\mathrm{~A}$ & 64.30 & $\mathrm{~B}$ & 57.70 & $\mathrm{C}$ & 50.61 & $\mathrm{D}$ & 43.38 & $\mathrm{E}$ & $38.51 \mathrm{~F}$ & \\
\hline & \multicolumn{11}{|c|}{ Season 2017} & \\
\hline Distilled water (control) & 64.76 & d-g & 56.19 & $\mathrm{jkl}$ & 47.47 & $\mathrm{pq}$ & 38.70 & tu & 30.98 & $\mathrm{w}$ & $26.10 x$ & 44.03 \\
\hline $0.2 \%$ imazalil (IMZ) & 67.91 & $a-d$ & 62.36 & fgh & 54.89 & $\mathrm{k}-\mathrm{n}$ & 47.15 & $\mathrm{pq}$ & 38.61 & tu & $33.74 \mathrm{vw}$ & 50.78 \\
\hline $10 \%$ gum arabic (GA) & 68.90 & $a b$ & 64.94 & $c-f$ & 59.19 & hij & 52.03 & mno & 43.49 & rs & 38.21 tu & 54.46 \\
\hline $2 \%$ potassium sorbate $(\mathrm{PS})$ & 68.90 & $a b$ & 63.79 & efg & 58.91 & hij & 51.63 & no & 42.68 & rs & 36.99 tuv & 53.82 \\
\hline 2\% potassium bicarbonate $(\mathrm{PB})$ & 68.41 & $a b c$ & 63.79 & efg & 58.33 & $\mathrm{ijk}$ & 50.41 & op & 42.27 & rs & $36.18 \mathrm{uv}$ & 53.23 \\
\hline $10 \%$ GA incorporated with $0.2 \%$ IMZ & 69.05 & $a b$ & 63.34 & efg & 58.08 & ijk & 52.49 & mno & 44.31 & $\mathrm{qr}$ & 40.33 st & 54.60 \\
\hline $10 \%$ GA incorporated with $2 \%$ PS & 70.95 & $\mathrm{a}$ & 66.19 & b-e & 61.11 & ghi & 55.55 & $j-m$ & 49.02 & op & $47.05 \mathrm{pq}$ & 58.31 \\
\hline $10 \%$ GA incorporated with $2 \%$ PB & 69.52 & $a b$ & 64.76 & d-g & 59.09 & hij & 54.40 & $\operatorname{lmn}$ & 47.45 & $\mathrm{pq}$ & 43.89 qrs & 56.52 \\
\hline Means & 68.55 & A & 63.17 & $\mathrm{~B}$ & 57.14 & $\mathrm{C}$ & 50.30 & $\mathrm{D}$ & 42.35 & E & $37.81 \mathrm{~F}$ & \\
\hline
\end{tabular}

Means followed by the same letters within postharvest treatments, storage periods and their interactions in each season are not significantly different at level $P \leq 0.05$ according to DMRT.

Egypt. J. Hort. Vol. 45, No.2 (2018) 
TABLE 9. Effect of some postharvest dip treatments on total soluble solids content ( $\left.{ }^{\circ} \mathrm{Brix}\right)$ of 'Washington' navel oranges after cold storage at $5 \pm 1^{\circ} \mathrm{C}$ followed by one week shelf life at $18-23^{\circ} \mathrm{C}$

\begin{tabular}{|c|c|c|c|c|c|c|c|c|c|c|c|c|}
\hline \multirow{3}{*}{ Postharvest treatments } & \multicolumn{11}{|c|}{ Storage period (weeks) } & \multirow{3}{*}{ Means } \\
\hline & ( & 0 & 2 & 2 & 4 & 4 & 6 & & 8 & 3 & 10 & \\
\hline & \multicolumn{11}{|c|}{ Season 2016} & \\
\hline Distilled water (control) & 9.00 & $\mathrm{~s}-\mathrm{V}$ & 9.67 & opq & 10.40 & $\mathrm{klm}$ & 11.13 & gh & 11.80 & cde & 12.53 & $10.76 \mathrm{~A}$ \\
\hline $0.2 \%$ imazalil (IMZ) & 8.93 & $\mathrm{t}-\mathrm{w}$ & 9.53 & $\mathrm{qr}$ & 10.33 & $\mathrm{klm}$ & 11.07 & ghi & 11.73 & cde & $12.33 \mathrm{ab}$ & $10.66 \mathrm{~A}$ \\
\hline $10 \%$ gum arabic $(\mathrm{GA})$ & 8.87 & $t-w$ & 9.33 & $q-\mathrm{t}$ & 10.13 & $1-0$ & 10.73 & h-k & 11.40 & efg & $11.93 \mathrm{bcd}$ & $10.40 \mathrm{~B}$ \\
\hline $2 \%$ potassium sorbate $(\mathrm{PS})$ & 8.93 & $\mathrm{t}-\mathrm{w}$ & 9.47 & qrs & 10.40 & $\mathrm{klm}$ & 11.13 & $\mathrm{gh}$ & 11.73 & cde & $12.60 \mathrm{a}$ & $10.71 \mathrm{~A}$ \\
\hline $2 \%$ potassium bicarbonate $(\mathrm{PB})$ & 9.00 & $\mathrm{~s}-\mathrm{v}$ & 9.47 & qrs & 10.53 & $j-m$ & 11.20 & fgh & 11.80 & cde & 12.67 & $10.78 \mathrm{~A}$ \\
\hline $10 \%$ GA incorporated with $0.2 \% \mathrm{IMZ}$ & 8.80 & uvw & 9.27 & $\mathrm{q}-\mathrm{u}$ & 10.07 & m-p & 10.60 & i-1 & 11.33 & efg & $12.20 \mathrm{abc}$ & $10.38 \mathrm{~B}$ \\
\hline $10 \%$ GA incorporated with $2 \%$ PS & 8.47 & $\mathrm{w}$ & 9.00 & $\mathrm{~s}-\mathrm{v}$ & 9.60 & pqr & 10.13 & $1-0$ & 10.93 & $g-j$ & $11.67 \mathrm{def}$ & $9.97 \mathrm{C}$ \\
\hline $10 \%$ GA incorporated with $2 \% \mathrm{~PB}$ & 8.53 & vw & 9.13 & $\mathrm{r}-\mathrm{u}$ & 9.73 & $n-q$ & 10.20 & $\operatorname{lmn}$ & 11.13 & $\mathrm{gh}$ & $12.00 \mathrm{bcd}$ & $10.12 \mathrm{C}$ \\
\hline \multirow[t]{2}{*}{ Means } & 8.82 & $\mathrm{~F}$ & 9.36 & $\mathrm{E}$ & 10.15 & $\mathrm{D}$ & 10.77 & $\mathrm{C}$ & 11.48 & $\mathrm{~B}$ & $12.24 \quad \mathrm{~A}$ & \\
\hline & \multicolumn{11}{|c|}{ Season 2017} & \\
\hline Distilled water (control) & 9.60 & $\mathrm{r}-\mathrm{u}$ & 9.80 & qrs & 10.80 & $\operatorname{lmn}$ & 11.40 & $\mathrm{ij}$ & 12.07 & $b-f$ & $12.47 \mathrm{abc}$ & $11.02 \mathrm{~A}$ \\
\hline $0.2 \%$ imazalil (IMZ) & 9.53 & $\mathrm{r}-\mathrm{v}$ & 9.73 & rs & 10.67 & mno & 11.33 & ijk & 11.93 & $\mathrm{~d}-\mathrm{h}$ & $12.40 \mathrm{a}-\mathrm{d}$ & $10.93 \mathrm{~A}$ \\
\hline $10 \%$ gum arabic $(\mathrm{GA})$ & 9.47 & $\mathrm{r}-\mathrm{w}$ & 9.60 & $\mathrm{r}-\mathrm{u}$ & 10.33 & nop & 10.80 & $\operatorname{lmn}$ & 11.67 & $e-i$ & $12.00 \mathrm{c}-\mathrm{g}$ & $10.64 \mathrm{~B}$ \\
\hline $2 \%$ potassium sorbate $(\mathrm{PS})$ & 9.60 & $\mathrm{r}-\mathrm{u}$ & 9.87 & $\mathrm{p}-\mathrm{s}$ & 10.73 & $1-0$ & 11.47 & hij & 12.07 & $b-f$ & $12.53 \mathrm{ab}$ & $11.04 \mathrm{~A}$ \\
\hline $2 \%$ potassium bicarbonate $(\mathrm{PB})$ & 9.67 & rst & 9.93 & pqr & 10.87 & $\mathrm{klm}$ & 11.53 & $g-j$ & 12.13 & $\mathrm{a}-\mathrm{e}$ & $12.60 \quad \mathrm{a}$ & $11.12 \mathrm{~A}$ \\
\hline $10 \%$ GA incorporated with $0.2 \% \mathrm{IMZ}$ & 9.33 & $\mathrm{~s}-\mathrm{w}$ & 9.47 & $\mathrm{r}-\mathrm{w}$ & 10.00 & pqr & 10.73 & $1-0$ & 11.60 & $f-i$ & $12.27 \mathrm{a}-\mathrm{d}$ & $10.57 \mathrm{~B}$ \\
\hline $10 \%$ GA incorporated with $2 \%$ PS & 9.00 & $\mathrm{w}$ & 9.07 & vw & 9.67 & rst & 10.27 & opq & 11.07 & $\mathrm{j}-\mathrm{m}$ & $11.60 \mathrm{f}-\mathrm{i}$ & $10.11 \mathrm{C}$ \\
\hline $10 \%$ GA incorporated with $2 \% \mathrm{~PB}$ & 9.13 & uvw & 9.20 & $\mathrm{t}-\mathrm{w}$ & 9.87 & $\mathrm{p}-\mathrm{s}$ & 10.33 & nop & 11.20 & $\mathrm{i}-1$ & $11.93 \mathrm{~d}-\mathrm{h}$ & $10.28 \mathrm{C}$ \\
\hline Means & 9.42 & $\mathrm{~F}$ & 9.58 & $\mathrm{E}$ & 10.37 & $\mathrm{D}$ & 10.98 & $\mathrm{C}$ & 11.72 & $\mathrm{~B}$ & $12.23 \quad \mathrm{~A}$ & \\
\hline
\end{tabular}

Means followed by the same letters within postharvest treatments, storage periods and their interactions in each season are not significantly different at level $P \leq 0.05$ according to DMRT.

TABLE 10. Effect of some postharvest dip treatments on titratable acidity percentage of 'Washington' navel oranges after cold storage at $5 \pm 1^{\circ} \mathrm{C}$ followed by one week shelf life at $18-23^{\circ} \mathrm{C}$

\begin{tabular}{|c|c|c|c|c|c|c|c|}
\hline \multirow{3}{*}{ Postharvest treatments } & \multicolumn{6}{|c|}{ Storage period (weeks) } & \multirow{3}{*}{ Means } \\
\hline & $\mathbf{0}$ & 2 & 4 & 6 & 8 & 10 & \\
\hline & \multicolumn{6}{|c|}{ Season 2016} & \\
\hline Distilled water (control) & 0.88 def & $0.73 \mathrm{ijk}$ & $0.64 \mathrm{mn}$ & 0.56 op & $0.45 \mathrm{st}$ & $0.41 \mathrm{t}$ & $0.61 \mathrm{G}$ \\
\hline $0.2 \%$ imazalil (IMZ) & $0.89 \mathrm{de}$ & $0.75 \mathrm{ij}$ & $0.65 \mathrm{mn}$ & 0.60 no & 0.49 qrs & $0.44 \mathrm{st}$ & $0.64 \mathrm{~F}$ \\
\hline $10 \%$ gum arabic $(\mathrm{GA})$ & $0.93 \mathrm{~cd}$ & $0.86 \mathrm{efg}$ & $0.75 \mathrm{ij}$ & $0.64 \mathrm{mn}$ & 0.56 op & $0.54 \mathrm{pq}$ & $0.71 \mathrm{D}$ \\
\hline $2 \%$ potassium sorbate $(\mathrm{PS})$ & $0.93 \mathrm{~cd}$ & $0.83 \mathrm{fgh}$ & $0.72 \mathrm{jkl}$ & $0.64 \mathrm{mn}$ & $0.53 \mathrm{pqr}$ & $0.47 \mathrm{rs}$ & $0.69 \mathrm{E}$ \\
\hline $2 \%$ potassium bicarbonate $(\mathrm{PB})$ & $0.93 \mathrm{~cd}$ & $0.79 \mathrm{hi}$ & $0.68 \mathrm{klm}$ & $0.64 \mathrm{mn}$ & $0.53 \mathrm{pqr}$ & $0.47 \mathrm{rs}$ & $0.67 \mathrm{E}$ \\
\hline $10 \%$ GA incorporated with $0.2 \% \mathrm{IMZ}$ & $0.95 \mathrm{bc}$ & $0.88 \mathrm{def}$ & $0.81 \mathrm{gh}$ & $0.68 \mathrm{~lm}$ & 0.60 no & 0.56 op & $0.75 \mathrm{C}$ \\
\hline $10 \%$ GA incorporated with $2 \%$ PS & $1.03 \mathrm{a}$ & $0.95 \mathrm{bc}$ & $0.89 \mathrm{de}$ & $0.83 \mathrm{fgh}$ & $0.75 \mathrm{ij}$ & $0.68 \mathrm{~lm}$ & $0.85 \mathrm{~A}$ \\
\hline $10 \%$ GA incorporated with $2 \% \mathrm{~PB}$ & $0.99 \mathrm{ab}$ & $0.88 \mathrm{def}$ & $0.81 \mathrm{gh}$ & $0.75 \mathrm{ij}$ & $0.68 \mathrm{~lm}$ & 0.60 no & $0.79 \mathrm{~B}$ \\
\hline \multirow[t]{2}{*}{ Means } & $0.94 \mathrm{~A}$ & $0.83 \mathrm{~B}$ & $0.74 \mathrm{C}$ & $0.67 \mathrm{D}$ & $0.57 \mathrm{E}$ & $0.52 \mathrm{~F}$ & \\
\hline & \multicolumn{6}{|c|}{ Season 2017} & \\
\hline Distilled water (control) & 0.96 cde & $0.83 \mathrm{hi}$ & $0.73 \mathrm{k}$ & $0.61 \mathrm{mn}$ & 0.53 o & $0.41 \mathrm{r}$ & $0.68 \mathrm{~F}$ \\
\hline $0.2 \%$ imazalil (IMZ) & $0.97 \mathrm{~cd}$ & $0.86 \mathrm{gh}$ & $0.72 \mathrm{k}$ & $0.60 \mathrm{mn}$ & 0.53 ор & $0.44 \mathrm{qr}$ & $0.69 \mathrm{~F}$ \\
\hline $10 \%$ gum arabic $(\mathrm{GA})$ & $1.01 \mathrm{bc}$ & $0.90 \mathrm{fg}$ & $0.82 \mathrm{hi}$ & $0.68 \mathrm{kl}$ & 0.56 no & 0.54 o & $0.75 \mathrm{D}$ \\
\hline $2 \%$ potassium sorbate $(\mathrm{PS})$ & $1.01 \mathrm{bc}$ & $0.86 \mathrm{gh}$ & $0.79 \mathrm{ij}$ & $0.64 \mathrm{~lm}$ & 0.56 no & $0.47 \mathrm{pq}$ & $0.72 \mathrm{E}$ \\
\hline $2 \%$ potassium bicarbonate $(\mathrm{PB})$ & $0.97 \mathrm{~cd}$ & $0.86 \mathrm{gh}$ & $0.79 \mathrm{ij}$ & $0.64 \mathrm{~lm}$ & 0.56 no & $0.47 \mathrm{pq}$ & $0.72 \mathrm{E}$ \\
\hline $10 \%$ GA incorporated with $0.2 \% \mathrm{IMZ}$ & $1.05 \mathrm{ab}$ & $0.92 \mathrm{~d}-\mathrm{g}$ & $0.87 \mathrm{gh}$ & $0.73 \mathrm{jk}$ & $0.64 \mathrm{~lm}$ & 0.53 op & $0.79 \mathrm{C}$ \\
\hline $10 \%$ GA incorporated with $2 \%$ PS & $1.09 \mathrm{a}$ & 0.96 cde & 0.94 def & $0.90 \mathrm{fg}$ & $0.83 \mathrm{hi}$ & $0.79 \mathrm{ij}$ & $0.92 \mathrm{~A}$ \\
\hline $10 \%$ GA incorporated with $2 \% \mathrm{~PB}$ & $1.07 \mathrm{a}$ & 0.94 def & $0.90 \mathrm{efg}$ & $0.83 \mathrm{hi}$ & $0.73 \mathrm{k}$ & $0.64 \mathrm{~lm}$ & $0.85 \mathrm{~B}$ \\
\hline Means & $1.02 \mathrm{~A}$ & $0.89 \mathrm{~B}$ & $0.82 \mathrm{C}$ & $0.70 \mathrm{D}$ & $0.62 \mathrm{E}$ & $0.54 \mathrm{~F}$ & \\
\hline
\end{tabular}

Means followed by the same letters within postharvest treatments, storage periods and their interactions in each season are not significantly different at level $P \leq 0.05$ according to DMRT. 
TABLE 11. Effect of some postharvest dip treatments on total soluble solids/titratable acidity ratio of 'Washington' navel oranges after cold storage at $5 \pm 1^{\circ} \mathrm{C}$ followed by one week shelf life at $18-23^{\circ} \mathrm{C}$

\begin{tabular}{|c|c|c|c|c|c|c|c|c|}
\hline \multirow{3}{*}{ Postharvest treatments } & \multicolumn{7}{|c|}{ Storage period (weeks) } & \multirow{3}{*}{ Means } \\
\hline & $\mathbf{0}$ & & 2 & 4 & 6 & 8 & 10 & \\
\hline & \multicolumn{7}{|c|}{ Season 2016} & \\
\hline Distilled water (control) & 10.33 & $\mathrm{r}-\mathrm{v}$ & $13.251-\mathrm{r}$ & $16.32 \mathrm{~h}-\mathrm{l}$ & 20.33 efg & $26.19 \mathrm{bc}$ & $30.97 \mathrm{a}$ & $19.57 \mathrm{~A}$ \\
\hline $0.2 \%$ imazalil (IMZ) & 10.17 & $\mathrm{r}-\mathrm{v}$ & $12.77 \mathrm{~m}-\mathrm{s}$ & $16.04 \mathrm{~h}-1$ & $18.57 \mathrm{f}-\mathrm{i}$ & $24.27 \mathrm{~cd}$ & $28.38 \mathrm{ab}$ & $18.37 \mathrm{~B}$ \\
\hline $10 \%$ gum arabic (GA) & 9.61 & $\mathrm{~s}-\mathrm{v}$ & $11.14 \mathrm{p}-\mathrm{v}$ & $13.57 \mathrm{k}-\mathrm{q}$ & 16.89 hij & 20.24 efg & $22.26 \mathrm{de}$ & $15.62 \mathrm{C}$ \\
\hline $2 \%$ potassium sorbate $(\mathrm{PS})$ & 9.68 & $\mathrm{~s}-\mathrm{v}$ & $12.19 \mathrm{n}-\mathrm{u}$ & $14.74 \mathrm{j}-\mathrm{o}$ & $18.70 \mathrm{f}-\mathrm{i}$ & $22.49 \mathrm{de}$ & $27.00 \mathrm{bc}$ & $17.47 \mathrm{~B}$ \\
\hline $2 \%$ potassium bicarbonate $(\mathrm{PB})$ & 9.66 & $s-\mathrm{V}$ & $12.16 \mathrm{n}-\mathrm{u}$ & $15.76 \mathrm{i}-\mathrm{m}$ & $17.82 \mathrm{~g}-\mathrm{j}$ & $22.70 \mathrm{de}$ & $27.13 \mathrm{~b}$ & $17.54 \mathrm{~B}$ \\
\hline $10 \% \mathrm{GA}$ incorporated with $0.2 \% \mathrm{IMZ}$ & 9.26 & uv & $10.52 \mathrm{q}-\mathrm{v}$ & $12.58 \mathrm{n}-\mathrm{t}$ & $15.68 \mathrm{i}-\mathrm{m}$ & $19.00 \mathrm{fgh}$ & $22.29 \mathrm{de}$ & $14.89 \mathrm{C}$ \\
\hline $10 \%$ GA incorporated with $2 \%$ PS & 8.33 & $\mathrm{v}$ & 9.47 tuv & $10.87 \mathrm{p}-\mathrm{V}$ & $12.31 \mathrm{n}-\mathrm{u}$ & $15.16 j-n$ & $17.70 \mathrm{~g}-\mathrm{j}$ & $12.31 \mathrm{E}$ \\
\hline $10 \%$ GA incorporated $\mathrm{w}$ & 8.68 & $\mathrm{v}$ & $10.47 \mathrm{q}-\mathrm{v}$ & $12.00 \mathrm{o}-\mathrm{u}$ & $13.67 \mathrm{k}-\mathrm{p}$ & $16.47 \mathrm{~h}-\mathrm{k}$ & 21.03 ef & $13.72 \mathrm{D}$ \\
\hline \multirow[t]{2}{*}{ Means } & 9.46 & $\mathrm{~F}$ & $11.50 \mathrm{E}$ & $13.98 \mathrm{D}$ & $16.75 \mathrm{C}$ & $20.82 \mathrm{~B}$ & $24.60 \mathrm{~A}$ & \\
\hline & \multicolumn{7}{|c|}{ Season 2017} & \\
\hline Distilled water & 10.04 & o-s & $11.831-q$ & $15.02 \mathrm{jk}$ & $18.92 \mathrm{efg}$ & $22.84 \mathrm{c}$ & $30.82 \mathrm{a}$ & $18.25 \mathrm{~A}$ \\
\hline $0.2 \% \mathrm{i}$ & 9.85 & $\mathrm{p}-\mathrm{s}$ & $11.43 \mathrm{~m}-\mathrm{s}$ & $15.06 \mathrm{jk}$ & 19.19 efg & $22.96 \mathrm{c}$ & $28.55 \mathrm{ab}$ & $17.84 \mathrm{AB}$ \\
\hline $10 \%$ gum arabic $(\mathrm{GA})$ & 9.40 & qrs & $10.65 \mathrm{n}-\mathrm{s}$ & $13.09 \mathrm{k}-\mathrm{o}$ & $16.36 \mathrm{~g}-\mathrm{j}$ & $20.72 \mathrm{c}-\mathrm{f}$ & $22.35 \mathrm{~cd}$ & $15.43 \mathrm{C}$ \\
\hline $2 \%$ potassium sorbate $(\mathrm{PS})$ & 9.53 & $\mathrm{p}-\mathrm{s}$ & $11.611-r$ & $14.83 \mathrm{jk}$ & $18.48 \mathrm{fgh}$ & $21.43 \mathrm{cde}$ & $26.83 \mathrm{~b}$ & $17.12 \mathrm{~B}$ \\
\hline $2 \%$ potassium bicarbonate $(\mathrm{PB})$ & 10.19 & o-s & $11.681-r$ & $13.92 \mathrm{j}-\mathrm{m}$ & $18.47 \mathrm{fgh}$ & 21.55 cde & $26.93 \mathrm{~b}$ & $17.12 \mathrm{~B}$ \\
\hline $10 \% \mathrm{GA}$ incorporated with $0.2 \% \mathrm{IMZ}$ & 8.97 & qrs & $10.34 \mathrm{n}-\mathrm{s}$ & $11.83 \mathrm{l}-\mathrm{q}$ & $14.63 \mathrm{jkl}$ & $18.27 \mathrm{f}-\mathrm{i}$ & $23.59 \mathrm{c}$ & $14.61 \mathrm{C}$ \\
\hline $10 \%$ GA incorporated with $2 \%$ PS & 8.29 & $\mathrm{~s}$ & 9.47 qrs & $10.31 \mathrm{n}-\mathrm{s}$ & $11.58 \mathrm{l}-\mathrm{r}$ & $13.39 \mathrm{j}-\mathrm{n}$ & $15.61 \mathrm{~h}-\mathrm{k}$ & $11.44 \mathrm{E}$ \\
\hline $10 \% \mathrm{GA}$ incorporated with $2 \% \mathrm{~PB}$ & 8.57 & rs & $9.80 \mathrm{p}-\mathrm{s}$ & $11.12 \mathrm{~m}-\mathrm{s}$ & $12.66 \mathrm{k}-\mathrm{p}$ & $15.50 \mathrm{ijk}$ & 19.79 def & $12.91 \mathrm{D}$ \\
\hline Means & 9.36 & $\mathrm{~F}$ & $10.85 \mathrm{E}$ & $13.15 \mathrm{D}$ & $16.29 \mathrm{C}$ & $19.58 \mathrm{~B}$ & $24.31 \mathrm{~A}$ & \\
\hline
\end{tabular}

Means followed by the same letters within postharvest treatments, storage periods and their interactions in each season are not significantly different at level $P \leq 0.05$ according to DMRT.

Our results are in line with the findings of Khaliq et al. (2015) who reported that the application of 'Choke Anan' mangoes with 10\% GA alone or combined with $3 \%$ calcium chloride significantly maintained high TA and AsA as compared to control during cold storage at $6^{\circ} \mathrm{C}$ for 28 days and additional five days shelf life at $25^{\circ} \mathrm{C}$. Similarly, treated banana and papaya fruits with $10 \%$ gum arabic alone or combined with $0.05 \%$ lemongrass oil or $0.4 \%$ cinnamon oil significantly delayed the rate of increase of TSS content and maintained the highest TA compared to essential oils alone and control after cold storage for 28 days and five days shelf life at room temperature (Maqbool et al., 2011). Moreover, coated mangoes with bentonite loaded with potassium sorbate significantly maintained high AsA content, preserved TA and delayed the accumulation of TSS as compared to uncoated fruits (Liu et al., 2014).

\section{Total phenolic content (TPC) and total antioxidant capacity (TAC)}

Results in Tables 12 and 13 demonstrate that, gradual and significant increase in TPC and TAC of 'Washington' navel oranges were observed during six weeks of cold storage period at $5^{\circ} \mathrm{C}$ plus one week shelf life at $18-23^{\circ} \mathrm{C}$ followed by a significant decrease at end of the experiment in the two seasons. These results indicate that, the significant highest peak of TPC (3.36 \& $3.65 \mathrm{mg}$ gallic acid/g fw) and TAC (230.15 \& $219.11 \mathrm{mg}$ $\alpha$-tocopherol/100 g fw) in 2016 and 2017 seasons, respectively were recorded at six weeks of storage period. After that, TPC and TAC were significantly declined after end of cold storage period followed by one week shelf life and the values reached of $2.55 \& 2.75 \mathrm{mg}$ gallic acid $/ \mathrm{g}$ fw and $170.65 \&$ $180.87 \mathrm{mg} \alpha$-tocopherol/100 $\mathrm{g} \mathrm{fw}$, respectively in the first and second seasons, respectively.

On the average, results also show that, all postharvest applications of 'Washington' navel oranges significantly increased TPC and TAC as compared to water control or treated oranges with imazalil after cold storage at $5^{\circ} \mathrm{C}$ followed by one week shelf life at $18-23^{\circ} \mathrm{C}$ in the two seasons. Moreover, combined treatments of gum arabic and potassium sorbate or potassium bicarbonate were superior to individual treatment and gum arabic incorporated with imazalil. Postharvest treatment of navel oranges with $2 \%$ potassium sorbate incorporated with $10 \%$ gum arabic recorded the significant highest of TPC $(3.89 \& 4.21 \mathrm{mg}$ gallic acid/g fw) and TAC (260.62 \& $252.45 \mathrm{mg}$ $\alpha$-tocopherol/100 g fw) in 2016 and 2017 seasons, respectively followed by treated navel oranges with $2 \%$ potassium bicarbonate incorporated with $10 \%$ gum arabic. On the other hand, untreated fruits (control) showed the significant lowest of TPC (2.04 \& $2.21 \mathrm{mg}$ gallic acid/g fw) and TAC 
(136.96 \& $135.35 \mathrm{mg} \alpha$-tocopherol/100 $\mathrm{g} \mathrm{fw}$ ) in the first and second seasons, respectively followed by treated oranges with $0.2 \%$ imazalil.

Referring to the interaction effect, there was a significant interaction between postharvest treatments and storage periods at $p \leq 0.05$ for TPC and TAC in both seasons. Data declare that, the significant highest peak of TPC of individual treatments were recorded after two weeks of cold storage period followed by shelf life, while this peak of combined treatments was recorded after six weeks of cold storage period followed by shelf life in both seasons. Moreover, the highest peak of TAC of individual and incorporated treatments was observed after six weeks of cold storage period followed by shelf life in the two seasons. On contrary, untreated fruits and treated with $0.2 \%$ imazalil showed gradual and significant decrease of TPC and TAC during cold storage period followed by shelf life in both seasons. Our results indicate that, after the end of cold storage period followed by shelf life, postharvest treatment of orange fruits with $2 \%$ potassium sorbate incorporated with $10 \%$ gum arabic had the significant highest values of TPC ( $3.63 \& 3.92 \mathrm{mg}$ gallic acid $/ \mathrm{g}$ fw $)$ and TAC (243.63 \& $258.22 \mathrm{mg} \alpha$-tocopherol/100 g fw) in the first and second seasons, respectively. On the opposite, untreated fruits (control) had the significant lowest values of TPC (1.38 \& $1.49 \mathrm{mg}$ gallic acid $/ \mathrm{g}$ fw) and TAC (96.85 \& $102.64 \mathrm{mg} \alpha$-tocopherol/100 $\mathrm{g}$ fw) in 2016 and 2017 seasons, respectively.
Phenolic possesses antioxidant properties and serve as protective mechanisms in fruits. TPC has a defense mechanism against the invasion of plant pathogens and playing an important role in plant resistance (Beckman, 2000). Moreover, the presence of antioxidants and phenols could be substantially reduced the reactive oxygen species (ROS) and prevented lipid peroxidation of plant tissue by trapping the lipid alkoxyl radical (Blokhina et al., 2003).

The effect of postharvest treatments especially applications of gum arabic incorporated with potassium sorbate or potassium bicarbonate coating in maintaining TPC and enhancing TAC could be ascribed to ability to scavenging the excess ROS and consequently reducing the oxidative damage of the fruit (Khaliq et al., 2016 and Vargas-Torres et al., 2017). Therefore, these treatments delayed the senescence process of orange fruits as compared to control. Previously, a positive correlation among TPC and TAC has also been reported in mangoes (Khaliq et al., 2016). Therefore, in our study, the maximum amount of TPC in treated oranges especially $10 \%$ gum arabic incorporated with $2 \%$ potassium sorbate or $2 \%$ potassium bicarbonate means that those fruit maintained higher TAC than uncoated fruits or treated with $0.2 \%$ imazalil, which means that treated fruit enhanced the resistance of plant tissues to pathogens and reducing their physiological deterioration.

TABLE 12. Effect of some postharvest dip treatments on total phenolic content ( $\mathrm{mg}$ gallic acid/g fw) of 'Washington' navel oranges after cold storage at $5 \pm 1^{\circ} \mathrm{C}$ followed by one week shelf life at $18-23^{\circ} \mathrm{C}$

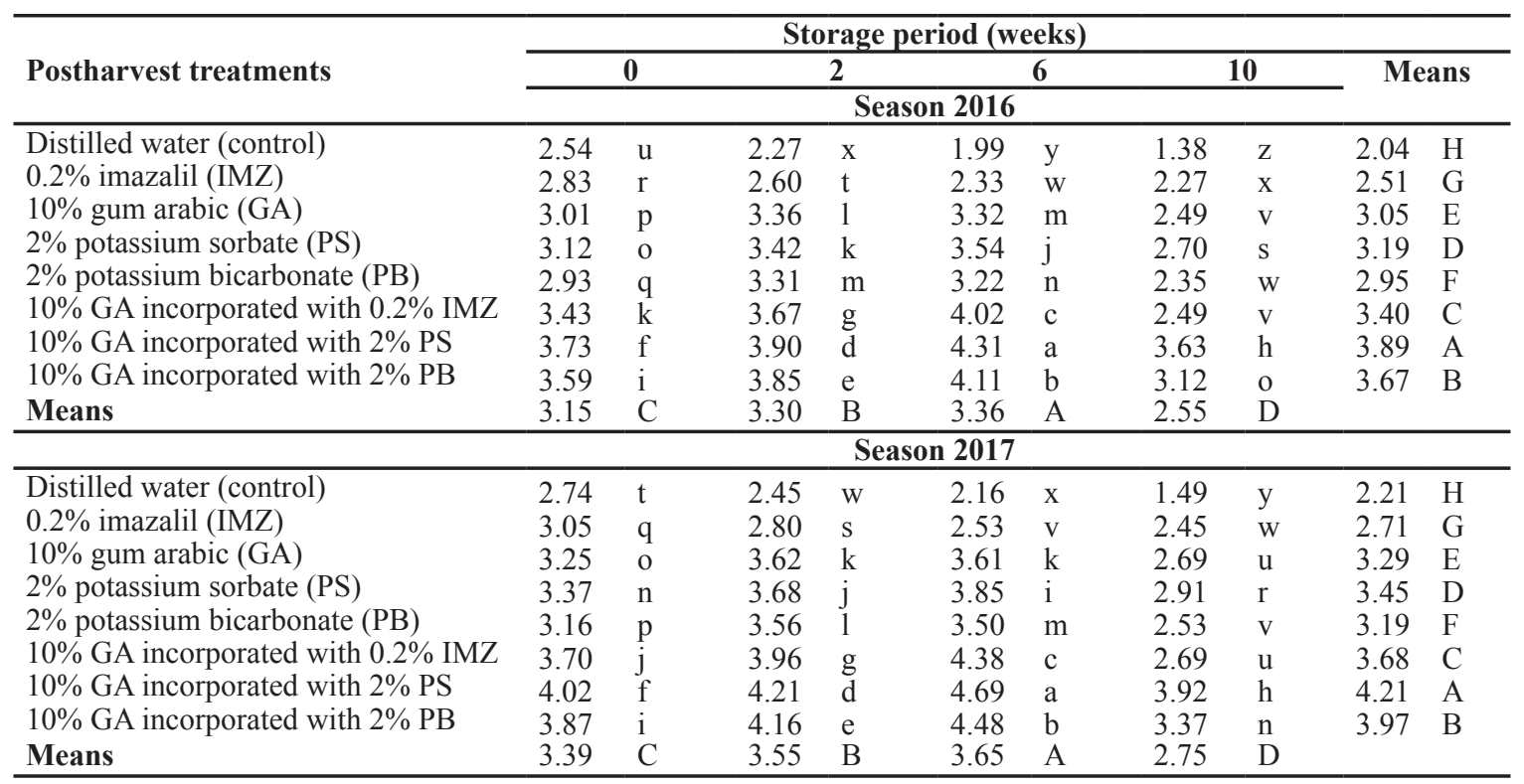

Means followed by the same letters within postharvest treatments, storage periods and their interactions in each season are not significantly different at level $P \leq 0.05$ according to DMRT. 
TABLE 13. Effect of some postharvest dip treatments on total antioxidant capacity (mg $\alpha$-tocopherol/100 $\mathrm{g}$ fw) of 'Washington' navel oranges after cold storage at $5 \pm 1^{\circ} \mathrm{C}$ followed by one week shelf life at $18-23^{\circ} \mathrm{C}$

\begin{tabular}{|c|c|c|c|c|c|c|c|c|c|c|}
\hline \multirow{3}{*}{ Postharvest treatments } & \multicolumn{8}{|c|}{ Storage period (weeks) } & \multirow{3}{*}{\multicolumn{2}{|c|}{ Means }} \\
\hline & \multirow{2}{*}{\multicolumn{2}{|c|}{0}} & \multirow{2}{*}{2} & & \multirow{2}{*}{\multicolumn{2}{|c|}{ 6 }} & \multirow{2}{*}{\multicolumn{2}{|c|}{10}} & & \\
\hline & & & & & & & & & & \\
\hline Distilled water (control) & 177.83 & $\mathrm{~s}$ & 150.17 & $\mathrm{v}$ & 123.00 & $\mathrm{x}$ & 96.85 & $\mathrm{z}$ & 136.96 & $\mathrm{H}$ \\
\hline $0.2 \%$ imazalil (IMZ) & 180.59 & $\mathrm{r}$ & 170.67 & $\mathrm{t}$ & 148.24 & $\mathrm{w}$ & 114.52 & $\mathrm{y}$ & 153.50 & G \\
\hline $10 \%$ gum arabic $(\mathrm{GA})$ & 200.46 & o & 235.55 & $\mathrm{j}$ & 239.14 & $\mathrm{i}$ & 170.43 & $\mathrm{t}$ & 211.40 & $\mathrm{E}$ \\
\hline $2 \%$ potassium sorbate $(\mathrm{PS})$ & 221.53 & $\mathrm{~m}$ & 251.64 & $\mathrm{f}$ & 265.48 & $\mathrm{~d}$ & 176.86 & s & 228.88 & $\mathrm{D}$ \\
\hline $2 \%$ potassium bicarbonate $(\mathrm{PB})$ & 194.10 & $\mathrm{p}$ & 219.67 & $\mathrm{n}$ & 222.86 & 1 & 162.48 & $\mathrm{u}$ & 199.77 & $\mathrm{~F}$ \\
\hline $10 \%$ GA incorporated with $0.2 \% \mathrm{IMZ}$ & 234.38 & $\mathrm{k}$ & 240.02 & hi & 266.93 & c & 181.67 & $\mathrm{q}$ & 230.75 & $\mathrm{C}$ \\
\hline $10 \%$ GA incorporated with $2 \%$ PS & 240.38 & $\mathrm{~h}$ & 267.08 & c & 291.40 & a & 243.63 & $\mathrm{~g}$ & 260.62 & A \\
\hline $10 \%$ GA incorporated with $2 \%$ PB & 233.34 & $\mathrm{k}$ & 253.69 & $\mathrm{e}$ & 284.14 & $\mathrm{~b}$ & 218.79 & $\mathrm{n}$ & 247.49 & B \\
\hline \multirow[t]{2}{*}{ Means } & 210.32 & $\mathrm{C}$ & 223.56 & $\mathrm{~B}$ & 230.15 & A & 170.65 & $\mathrm{D}$ & & \\
\hline & & & & \multicolumn{5}{|c|}{ Season 2017} & & \\
\hline Distilled water (control) & 171.96 & $\mathrm{t}$ & 143.98 & $\mathrm{v}$ & 122.84 & $\mathrm{x}$ & 102.64 & $\mathrm{z}$ & 135.35 & \\
\hline $0.2 \%$ imazalil (IMZ) & 174.63 & s & 163.63 & $\mathrm{u}$ & 140.63 & $\mathrm{w}$ & 121.37 & $\mathrm{y}$ & 150.07 & $\mathrm{G}$ \\
\hline $10 \%$ gum arabic $(\mathrm{GA})$ & 193.85 & $\mathrm{o}$ & 225.84 & $\mathrm{k}$ & 226.87 & $\mathrm{j}$ & 180.63 & $\mathrm{r}$ & 206.80 & $\mathrm{E}$ \\
\hline $2 \%$ potassium sorbate $(\mathrm{PS})$ & 214.22 & 1 & 241.26 & $\mathrm{~g}$ & 251.86 & $\mathrm{e}$ & 187.45 & $q$ & 223.70 & $\mathrm{D}$ \\
\hline $2 \%$ potassium bicarbonate $(\mathrm{PB})$ & 187.69 & $\mathrm{q}$ & 210.61 & $\mathrm{n}$ & 211.42 & $\mathrm{~m}$ & 172.20 & $\mathrm{t}$ & 195.48 & $\mathrm{~F}$ \\
\hline $10 \%$ GA incorporated with $0.2 \%$ IMZ & 226.64 & j & 230.12 & $\mathrm{i}$ & 253.23 & $\mathrm{~d}$ & 192.54 & $\mathrm{p}$ & 225.63 & $\mathrm{C}$ \\
\hline $10 \%$ GA incorporated with $2 \%$ PS & 232.44 & $\mathrm{~h}$ & 242.71 & $\mathrm{f}$ & 276.45 & $\mathrm{a}$ & 258.22 & $\mathrm{c}$ & 252.45 & A \\
\hline $10 \%$ GA incorporated with $2 \%$ PB & 225.64 & $\mathrm{k}$ & 230.55 & $\mathrm{i}$ & 269.57 & $\mathrm{~b}$ & 231.89 & $\mathrm{~h}$ & 239.41 & $\mathrm{~B}$ \\
\hline Means & 203.38 & $\mathrm{C}$ & 211.09 & $\mathrm{~B}$ & 219.11 & A & 180.87 & $\mathrm{D}$ & & \\
\hline
\end{tabular}

Means followed by the same letters within postharvest treatments, storage periods and their interactions in each season are not significantly different at level $P \leq 0.05$ according to DMRT.

A low amount of TPC and TAC in untreated fruits or treated with $0.2 \%$ imazalil might be due to the higher rate of respiration, senescence and breakdown of cell structure during storage as mentioned by Addai et al. (2013). Thus, untreated fruits or treated with $0.2 \%$ imazalil failed to acquire the protection and deteriorated oranges quickly. These results of the present study are comparable with the previous findings of Addai et al. (2013) in papaya fruits. They reported that gum arabic coating effectively maintained TPC and TAC during storage in comparison to untreated fruits. In the same way, coated 'Choke Anan' mangoes with $10 \%$ gum arabic alone or in combination with 3\% calcium chloride effectively inhibited the loss of TPC and antioxidant activity (Khaliq et al., 2016). In addition, dipped jackfruit in potassium sorbate for five minutes alone or combined with $1000 \mathrm{~nL} / \mathrm{L}$ of 1-methylcyclopropene and different edible coatings significantly increased TPC and TAC as compared to control during cold storage at $4^{\circ} \mathrm{C}$ (Vargas-Torres et al., 2017).

\section{Conclusion}

In conclusion, this research offers potential new methods to the 'Washington' navel oranges for implementation of nonpolluting postharvest diseases management especially devoted to high added value of organic markets or export markets. The present study showed that, edible coating of $10 \%$ gum arabic (GA), $2 \%$ potassium sorbate (PS), $2 \%$ potassium bicarbonate (PB) and GA incorporated with PS or PB significantly reduced the deterioration of physical and chemical characteristics of 'Washington' navel oranges during long term storage at low temperature as compared to untreated fruits or treated fruits with IMZ. In particular, $2 \%$ PS or $2 \%$ PB incorporated with $10 \%$ GA coating was the most effective in this respect. Thus, this study recommends with use of PS or PB at $2 \%$ incorporated with GA at $10 \%$ postharvest application of 'Washington' navel oranges instead of the currently adopted IMZ to reduce the risk of fungicide usage for controlling postharvest decay and keeping fruit quality for 10 weeks at $5^{\circ} \mathrm{C}$ followed by one week shelf life at $18-23^{\circ} \mathrm{C}$.

Acknowledgments: the author is grateful to ElWady Company for Export Agricultural Products for providing imazalil. Also, the author would like to thank Dr. A.S. Korayem and M.I. Mohamed, MSc. for technical assistance and their help in estimation of fruit total phenolic content and total antioxidant capacity. 
Funding statements: the author declares that there is no received external funding for this study.

Conflicts of interest: the author declares that there are no conflicts of interest related to the publication of this study.

\section{References}

Addai, Z.R., Abdullah, A., Mutalib, S.A. and Musa, K.H. (2013) Effect of gum arabic on quality and antioxidant properties of papaya fruit during cold storage. International Journal of ChemTech Research, 5, 2854-2862.

Anonymous, (2017) Ministry of agriculture and land reclamation, economic affairs sector, bulletin of the agricultural statistics.

AOAC, (2005) Official Method of Analysis of Association of Official Analytical Chemist International. $18^{\text {th }}$ Edition. North Frederick Avenue, Gaithersburg, Maryland, USA.

Balasundram, N., Sundram, K. and Samman, S. (2006) Phenolic compounds in plants and agri-industrial by-products: antioxidant activity, occurrence, and potential uses. Food Chemistry, 99, 191-203.

Beckman, C.H. (2000) Phenolic-storing cells: key to programmed cell death and periderm formation in wilt disease resistance and in general defense response in plants. Physiological and Molecular Plant Pathology, 57, 101-110.

Blokhina, O., Virolainen, E. and Fagerstedt, K.V. (2003) Antioxidants, oxidative damage and oxygen deprivation stress: a review. Annals of Botany, 91, 179-194.

Cerioni, L., Bennasar, P.B., Lazarte, D., Sepulveda, M., Smilanick, J.L., Ramallo, J. and Rapisarda, V.A (2017) Conventional and reduced-risk fungicides to control postharvest diplodia and phomopsis stemend rot on lemons. Scientia Horticulturae, 225, 783-787.

Cerioni, L., Sepulveda, M., Rubio-Ames, Z., Volentini, S.I., rodríguez-Montelongo, L., Smilanick, J.L., Ramallo, J. and Rapisarda, V.A. (2013) Control of lemon postharvest diseases by low-toxicity salts combined with hydrogen peroxide and heat. Postharvest Biology and Technology, 83, 17-21.

Davidson, P.M. (1997) Chemical preservatives and natural antimicrobial compounds. In Doyle, M.P., Bechaut, L.R. and Montville, T.J. (Editions), food microbiology, fundamentals and frontiers. $A S M$ Press, Washington DC, USA, 520-556.

Dhall, R.K. (2013) Advances in edible coatings for fresh fruits and vegetables: a review. Critical Reviews in Food Science and Nutrition, 53 (5), 435-450.
Eckert, J.W. and Eaks, I.L. (1989) Postharvest disorders and diseases of citrus fruit. In: Reuther, W., Calavan, E.C. and Carman, G.E. (Edition), the citrus industry. Crop protection, postharvest technology, and early history of citrus research in California, Volume 5. Division of Agriculture and Natural Resources, University of California Press, Berkeley, CA, USA, 179-260.

El-Anany, A.M., Hassan, G.F.A. and Rehab Ali, F.M. (2009) Effects of edible coatings on the shelf-life and quality of Anna apple (Malus domestica Borkh) during cold storage. Journal of Food Technology, 7, 5-11.

Idris, O.H.M., Williams, P.A. and Phillips, G.O. (1998) Characterization of gum from Acacia Senegal trees of different age and location using multidetection gel permeation chromatography. Food Hydrocolloids, 12, 379-388.

Khaliq, G., Mohamed, M.T.M., Ali, A., Ding, P. and Ghazali, H.M. (2015) Effect of gum arabic coating combined with calcium chloride on physicochemical and qualitative properties of mango (Mangifera indica L.) fruit during low temperature storage. Scientia Horticulturae, 190, 187-194.

Khaliq, G., Mohamed, M.T.M., Ghazali, H.M., Ding, P. and Ali, A. (2016) Influence of gum arabic coating incorporated with calcium chloride on physiological, biochemical and quality responses of mango (Mangifera indica L.) fruit stored under low temperature stress. Postharvest Biology and Technology, 111, 362-369.

Lindsay, R.C. (1996) Food additives. In: Fennema, O.R. (Edition), food chemistry, $3^{\text {rd }}$ Edition. Marcel Decker Inc., NewYork, USA, 767-823.

Liu, K., Wang, X. and Young, M. (2014) Effect of bentonite/potassium sorbate coatings on the quality of mangos in storage at ambient temperature. Journal of Food Engineering, 137, 16-22.

Mapson, C.W. (1970) Vitamins in fruits: stability of L-ascorbic acid. In: biochemistry of fruits and their products. Academic Press, London, 376-387.

Maqbool, M., Ali, A., Alderson, P.G., Mohamed, M.T.M., Siddiqui, Y. and Zahid, N. (2011) Postharvest application of gum arabic and essential oils for controlling anthracnose and quality of banana and papaya during cold storage. Postharvest Biology and Technology, 62, 71-76.

Montesinos-Herrero, C., del Río, M.A., Pastor, C., Brunetti, O. and Palou, L. (2009) Evaluation of brief potassium sorbate dips to control postharvest Penicillium decay on major citrus species and cultivars. Postharvest Biology and Technology, 52, 117-125.

Egypt. J. Hort. Vol. 45, No.2 (2018) 
M-STAT (1993) A microcomputer program for the design, arrangement and analysis of agronomic research experiments. Michigan State University.

Murata, T. (1997) Citrus. In: Mitra, S.K (Ed.), postharvest physiology and storage of tropical and subtropical Fruits. CAB International, Wallington, UK., 21-40.

Nisperos-Carriedo, M.O. (1994) Edible coatings and films based on polysaccharides. In: Krochta, J.M., Baldwin, E.A., Nisperos-Carriedo, M.O. (Ed.), edible coatings and films to improve food quality. Technomic Publish. Co. Inc., Lancaster, USA, 322-323.

Omran, M., Mousa, M. and El-Said, A. (2002) The impact of the European Egyptian agreement on competitiveness of Egyptian fresh horticultural exports. Proceedings of the second congress on recent technologies in agriculture. Cairo University 28-30 October. Economical part, 713-727.

Palou, L., Smilanick, J.L. and Droby, S. (2008) Alternatives to conventional fungicides for the control of citrus postharvest green and blue molds. Stewart Postharvest Review, 2 (2), 1-16.

Palou, L., Usall, J., Smilanick, J.L., Aguilar, M.J. and Viñas, I. (2002) Evaluation of food additives and low-toxicity compounds as alternative chemicals for the control of Penicillium digitatum and Penicillium italicum on citrus fruit. Pest Management Science, 58 (5), 459-466.

Parra, J., Ripoll, G. and Orihuel-Iranzo, B. (2014) Potassium sorbate effects on citrus weight loss and decay control. Postharvest Biology and Technology, 96, 7-13.

Payasi, A., Mishra, N.N., Chaves, A.L.S. and Singh, R. (2009) Biochemistry of fruit softening: an overview. Physiology and Molecular Biology of Plants, 15, 103-113.

Prieto, P, Pineda, M and Aguilar, M. (1999) Spectrophotometric quantitation of antioxidant capacity through the formation of a phosphomolybdenum complex: Specific application to the determination of Vitamin E. Analytical Biochemistry, 269, 337-341.

Prusky, D. (2011) Reduction of the incidence of postharvest quality losses, and future Prospects. Food Security, 3, 463-474.

Scotter, M.J. and Castle, L. (2004) Chemical interactions between additives in food stuffs: a review. Food Additives and Contaminants, 21, 93-124.

Egypt. J. Hort. Vol. 45, No.2 (2018)
Slinkard, K. and Singleton, V.L. (1977) Total phenol analysis: automation and comparison with manual methods. American Journal of Enology and Viticulture, 28, 49-55.

Smilanick, J.L., Mansour, M.F., Mlikota Gabler, F. and Sorenson, D. (2008) Control of citrus postharvest green mold and sour rot by potassium sorbate combined with heat and fungicides. Postharvest Biology and Technology, 47, 226-238.

Tripathi, P. and Dubey, N.K. (2004) Exploitation of natural products as an alternative strategy to control postharvest fungal rotting of fruit and vegetables. Postharvest Biology and Technology, 32, 235-245.

USEPA, (1998) United States Environmental Protection Agency. Technical amendments to sodium bicarbonate and potassium bicarbonate, tolerance exemptions: correction of effective date under congressional review act (CRA) final rule. Federal Register, 63, 417-418.

Valencia-Chamorro, S.A., Pérez-Gago, M.B., del Río, M.A. and Palou, L. (2009) Effect of antifungal hydroxypropyl methylcellulose (HPMC)-lipid edible composite coatings on postharvest decay development and quality attributes of cold-stored 'Valencia' oranges. Postharvest Biology and Technology, 54 (2), 72-79.

Valero, D. and Serrano, D. (2010) Posharvest biology and technology for preserving fruit quality. $C R C$ Press, Boca Raton, USA, 16-18.

Vargas-Torres, A., Becerra-Loza, A.S, Sayago-Ayerdi, S.G., Palma-Rodríguez, H.M., García-Magaña, M.D. and Montalvo-González, E. (2017) Combined effect of the application of 1-MCP and different edible coatings on the fruit quality of jackfruit bulbs (Artocarpus heterophyllus Lam) during cold storage. Scientia Horticulturae, 214, 221-227

Waks, J., Schiffmann-Nadel, M., Lomaniec, E. and Chalutz, E. (1985) Relation between fruit waxing and development of rots in citrus fruit during storage. Plant Disease, 69 (10), 869-870.

Watkins, C. and Harman, J. (1981) Use of penetrometer to measure flesh firmness of fruit. Orchadist, N.Z., 14-16.

Wild, B.L. (1981) The effects of waxing citrus fruit Rural Newsletter, 79, 14-19. 
York, G.K. and Vaughn, R.H. (1964) Mechanisms in the inhibition of microorganisms by sorbic acid. Journal of Bacteriology, 88, 411-417.

Youssef, K., Ligorio, A., Nigro, F. and Ippolito, A. (2012a) Activity of salts incorporated in wax in controlling postharvest diseases of citrus fruit. Postharvest Biology and Technology, 65, 39-43.
Youssef, K., Sanzani, S.M., Myrta, A. and Ippolito, A. (2014) Effect of a novel potassium bicarbonate-based formulation against penicillium decay of oranges. Journal of Plant Pathology, 96 (2), 419-424.

(Received 16/04/2018, accepted $05 / 06 / 2018$

Youssef, K., Ligorio, A., Sanzani, S.M., Nigro, F. and Ippolito, A. (2012b) Control of storage diseases of citrus by pre- and postharvest application of salts. Postharvest Biology and Technology, 72, 57-63.

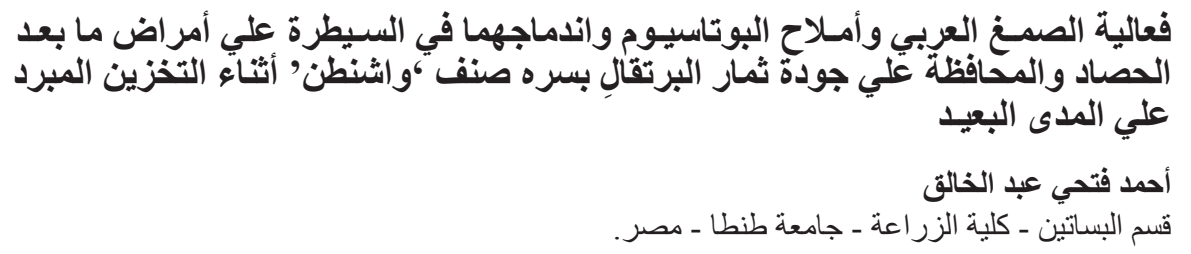

تم تقييم الصمغ العربي كطلاء صالح للأكل و المو اد الغذائية الحافظة التي لها خو اص معادية للفطريات متضنمنة

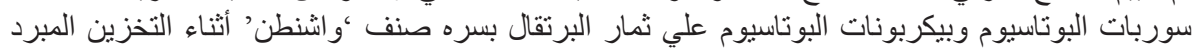

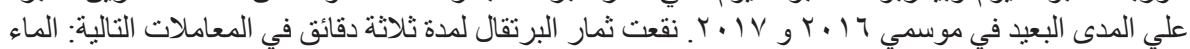

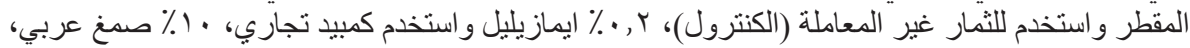

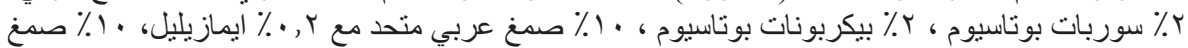

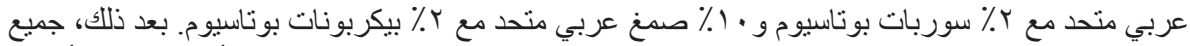

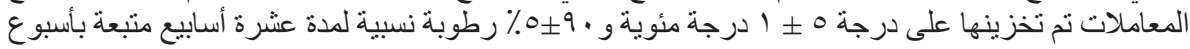

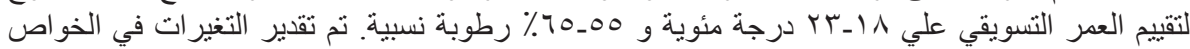

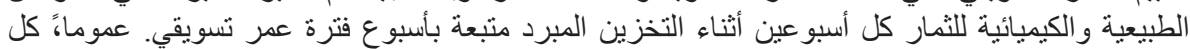

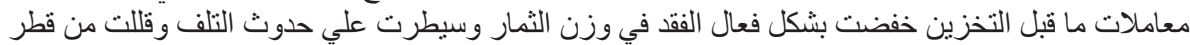

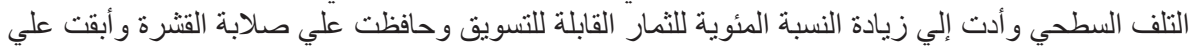

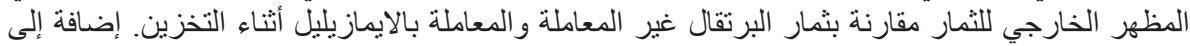

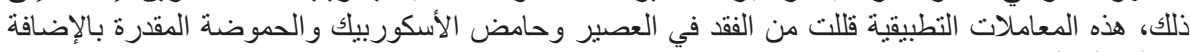

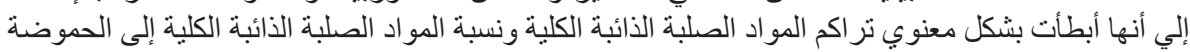

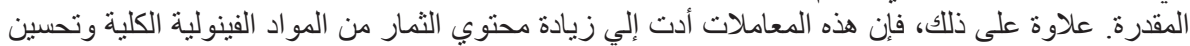

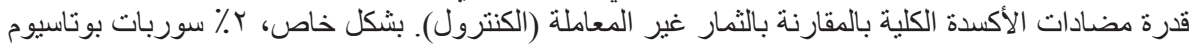

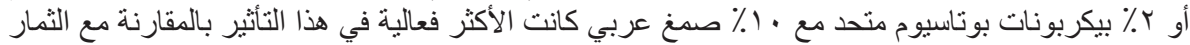

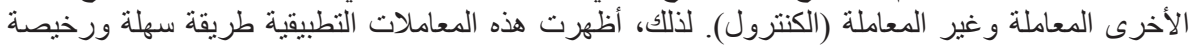

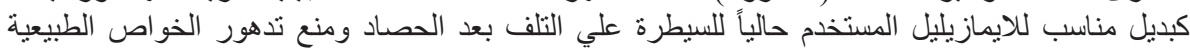

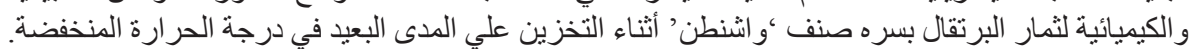

